\title{
20. ACOUSTIC FACIES AND SEDIMENT COMPOSITION OF THE MISSISSIPPI FAN DRILL SITES, DEEP SEA DRILLING PROJECT LEG 96 ${ }^{1}$
}

\author{
S. O'Connell, Lamont-Doherty Geological Observatory \\ and \\ W. R. Normark, U.S. Geological Survey²
}

\begin{abstract}
Four major acoustic facies units, mapped from high-resolution seismic profiles ( 3.5 and $4.5 \mathrm{kHz}$ ), are defined for the modern fan lobe of the Mississippi Fan: transparent, multiple reflector, diffuse prolonged, and hummocky. These acoustic units are compared with the general lithologic character and specific lithologic boundaries within sediment recovered in the upper $50 \mathrm{~m}$ from hydraulic piston cores at nine Deep Sea Drilling Project (DSDP) sites from the middle and lower Mississippi Fan.

Previous studies comparing short piston and gravity cores with acoustic facies in submarine fan areas indicate that specific lithologies can be expected to occur with specific acoustic facies. These earlier studies suggest that a good correlation exists between acoustic units and lithologies as follows: transparent and debris flow deposits, multiple reflectors and laminated sediments, diffuse prolonged and sand beds greater than $1 \mathrm{~m}$ thick, and hummocky and either debris flow or sediment-wave deposits.

In our study, correlation between lithologies and acoustic units (both within and between units) is inconsistent, ranging from excellent to poor. Excellent correlation is observed, at Sites 614 and 615 on the lower fan, between the multiplereflector unit and bedded sediments, and the diffuse-prolonged reflector unit and thick sand beds. Another good correlation occurs between dipping silt beds and laminations, cored at Site 616, and the hummocky unit. At both Sites 621 and 622 , we drilled into the transparent unit in the midfan channel and recovered visually homogeneous mud with poorly developed grading detectable in $\mathrm{x}$-radiographs. These sediment textures suggest deposition from a very sluggish masstransport process, such as might be expected in the transition between a debris flow and a high-density turbidity current.

Correlation between lithologies and acoustic facies at Sites 617, 623, and 624 is less clear. At all three sites, we recovered laminated and thinly bedded silts in a mud matrix, with the percentage of silt increasing downsection. It appears that at these sites the diffuse-prolonged return is caused by acoustic interference from many small lithologic changes rather than the presence of thicker sand beds.
\end{abstract}

\section{INTRODUCTION}

The Mississippi Fan is a Pleistocene accumulation of sediments that formed seaward of the Mississippi Delta (Moore et al., 1978). The present morphology is dominated by a sinuous channel-overbank system that can be followed almost the entire length of the modern fan lobe (introductory chapter, this volume). In this study we (1) classify high-resolution (3.5- and $4.5-\mathrm{kHz})$ seismic profiles into acoustic facies units, (2) discuss the inferred lithology and sedimentology of these acoustic facies, and (3) compare the inferred acoustic properties with the sediments recovered in the upper $50 \mathrm{~m}$ of nine DSDP sites. We chose $50 \mathrm{~m}$ because acoustic penetration never exceeded $50 \mathrm{~m}$.

High-resolution seismic profiles are commonly used in three ways: (1) to describe and map the general acoustic character of the profile (acoustic facies), (2) to relate the acoustic facies to the general inferred sediment texture and depositional mode (sedimentary facies), and (3) to relate the specific reflectors to specific lithologic contrasts in the core.

\footnotetext{
${ }^{1}$ Bouma, A. H., Coleman, J. M., Meyer, A. W., et al., Init. Repts. DSDP, 96: Washington (U.S. Govt. Printing Office)

2 Addresses: (O'Connell, present address) Ocean Drilling Program, 500 University Drive West, Texas A\&M University, College Station, TX 77843; (Normark) Pacific Branch of Marine Geology, U.S. Geological Survey (MS-999), 345 Middlefield Rd., Menlo Park, CA 94025.
}

Relating acoustic facies to sedimentary facies assumes that changes in seafloor acoustic reflectivity are caused by changes in sediment texture and composition. This assumption has been generally substantiated through examination of $3.5-\mathrm{kHz}$ profiles from different physiographic provinces in the ocean combined with data from cores, bottom photographs, current meters, and nephelometers. It is possible, however, that the depositional processes for different types of sediment, for example, flutes and tool marks in coarse-grained sediment versus hemipelagic settling in fine-grained sediment, are also a major contributing factor to acoustic reflectivity.

Acoustic facies units are determined from individual seismic profiles and displayed in plan view on acoustic facies maps (Damuth, 1980). These maps are useful in delineating lateral changes in lithology and depositional processes, particularly the distribution and abundance of sediments deposited by mass-wasting processes, such as slumps, slides, debris flows, and turbidity currents and the presence of bedforms such as sediment waves.

Bedded turbidites are recognized by three acoustic facies that show a qualitative correlation with the relative abundance of coarse sediments: (1) distinct returns with continuous sub-bottoms are recorded from areas with little or no coarse sediment; (2) indistinct, semi-diffuseprolonged returns with intermittent, indistinct, and discontinuous sub-bottoms are from areas with many thin 
silt and sand beds, and (3) strong diffuse-prolonged returns occur in areas with a high percentage of sand and silt in thick ( $>100 \mathrm{~cm}$ ) beds (Damuth, 1975). Hummocky or hyperbolic echoes occur in a wide variety of types and sizes and are returned from areas of gently undulating to rugged seafloor topography. These echoes are thought to reflect erosional/depositional bedforms created largely by deep thermohaline-induced flow (Damuth, 1975; Flood and Hollister, 1974), by turbiditycurrent flow (Normark, 1970; Damuth, 1975), or areas that have undergone mass-wasting processes may also produce hummocky returns (Walker and Massingill, 1970; Damuth, 1975; Embley, 1975; Cook et al., 1982; Cook and Mullins, 1983).

Slumps and debris flows also commonly appear as convex, lens-shaped transparent or internally chaotic and hyperbolic layers, or may have an indistinct, prolonged bottom return. They range in size from less than 1 to over 30,000 km² (Embley, 1975; Jacobi, 1976; Embley and Jacobi, 1977; Embley, 1980; Cook et al., 1982; Cook and Mullins, 1983).

The relationship between acoustic facies and sediment type is not clear. In some areas, widely spaced and abrupt changes in sediment composition have been related to prominent reflectors (Embley and Johnson, 1980). In other areas, however, distinct reflectors are observed where there are no visually apparent lithologic changes (Damuth, 1980). The importance of parameters other than visually apparent lithologic boundaries in producing reflectors on high-resolution profiles has been shown through detailed chemical and physical property studies on closely spaced samples from other sedimentary cores (e.g., Mayer, 1979, 1980; Flood and Shor, 1984).

Mayer $(1979,1980)$ investigated this problem in the eastern equatorial Pacific. There, distinct reflectors were observed on $4-\mathrm{kHz}$ seismic profiles but no lithologic boundaries were apparent in the cores. Mayer calculated acoustic impedance from closely spaced velocity and bulkdensity measurements to generate a reflection coefficient $\log$ for the cores. The synthetic seismogram thus derived did not correspond to reflectors seen on the deep-tow (Speiss and Tyce, 1973) 4-kHz profile taken near the piston core. When the reflection coefficient log was convolved with the outgoing $4-\mathrm{kHz}$ pulse, however, a synthetic seismogram was generated that did resemble the original profile. Changes in the frequency of the outgoing pulse produced changes in the amplitude and position of the reflectors in the synthetic profiles, leading to the conclusion that reflectors observed on the $4-\mathrm{kHz}$ profile are caused by the interference of many small impedance contrasts rather than discrete geologic horizons.

In a different study, Flood and Shor (1984) computed acoustic impedance using calcium carbonate sediment measurements, made at $10 \mathrm{~cm}$ intervals over $62 \mathrm{~m}$ of cored section from Hole $515 \mathrm{~A}$ in the southwest Brazil Basin. By convolving the acoustic impedance log with a 3.5-kHz seismic pulse, Flood and Shor (1984) generated a synthetic seismogram. The close correlation between the resulting synthetic seismogram and the original 3.5$\mathrm{kHz}$ profile suggested that carbonate content is controlling the $3.5-\mathrm{kHz}$ record at this site.

\section{METHODS}

Three different cruises produced the high-resolution seismic reflection profiles used in this study: a site-survey cruise in December 1982, an EDO deep-tow survey in early 1983, and the underway geophysical data collection aboard the Glomar Challenger during Leg 96. The sitesurvey cruise was conducted aboard the Conrad using a shipboard $3.5-\mathrm{kHz}$ profiler, an 80 -in ${ }^{3}$ water-gun system, and a deep-towed instrument package, Sea MARC I, which consists of two side-looking sonars at 27 and $30 \mathrm{kHz}$ and a downward-looking $4.5-\mathrm{kHz}$ sub-bottom profiler (Chayes, 1983). Two detailed areas (Fig. 1A), one on the middle fan and one on the lower fan, were surveyed on a grid pattern with approximately 1 - to $2-\mathrm{km}$ line spacing (Fig. 1B, C). Additional data collected during the transit between the two detailed study areas include the transition Sites 623 and 624 . A deep-tow survey using the EDO-Western 4075 dual $100-\mathrm{kHz}$ side-scan and $3.5-\mathrm{kHz}$ sub-bottom profiler was also conducted on the midfan. This survey, conducted during January 1983, collected over $100 \mathrm{~km}$ of data at a side-scan range of $200 \mathrm{~m}$ (Prior et al., 1983). Underway geophysical profiling aboard the Challenger consisted of $3.5-$ and $12-\mathrm{kHz}$ precision echo sounders, either an 80 -in. ${ }^{3}$ water gun or two Bolt air guns, and a magnetometer (Explanatory Notes, this volume).

Reflection profiles obtained immediately before drilling at each site, as well as those from earlier cruises, were used to determine (1) general acoustic facies and (2) depth of specific acoustic reflectors. Traveltime was measured from the seafloor to the top of each reflecting horizon. For conversion of reflector time to depth, we used a formula that was developed from borehole analyses in the shallower areas of the Mississippi canyon-fan system (Explanatory Notes, this volume). The formula is $D=0.762 \times R+0.00016 \times R^{2}$, where $R=$ two-way traveltime in milliseconds and $D=$ depth in meters.

Shipboard sonic velocity measurements, measured parallel to bedding, range from about $1.4 \mathrm{~km} / \mathrm{s}$ at the surface to $1.6 \mathrm{~km} / \mathrm{s}$ at $50 \mathrm{~m}$. Velocities from four sites are given in Table 1. The derivative of the formula gives velocities that range from $1.524 \mathrm{~km} / \mathrm{s}$ at the surface to $1.565 \mathrm{~km} / \mathrm{s}$ at $50 \mathrm{~m}$ (Table 1). There is a maximum difference of 0.13 $\mathrm{km} / \mathrm{s}$. At $50 \mathrm{~m}$ this would result in a vertical difference of about $5 \mathrm{~m}$. A velocity difference of $0.04 \mathrm{~km} / \mathrm{s}$ would result in a vertical difference of $2 \mathrm{~m}$ at $50 \mathrm{~m}$. Therefore we assume our reflector depths to be accurate to within $5 \mathrm{~m}$.

Additional sonic velocity data are available from Flood and Bryan (1983). In a series of hydrophone-pinger experiments, they generated wide-angle seismic reflection profiles at the seabed. Their midfan velocity values, for one run on the eastern midfan levee, are given in Table 1. Velocities are generally higher than those derived from the formula given above and the shipboard measurements. On the lower fan, however, no coherent wide-angle reflections could be followed on the deep hydrophone records, and therefore no velocities were determined. Two possible reasons are given (Flood and Bryan, 1983) for the lack of coherent wide-angle reflections: (1) surface roughness which may have scattered the sound and (2) changing interference patterns between closely spaced reflecting surfaces.

Lithologic boundaries are determined by visual inspection and smearslide analysis of the cores.

\section{RESULTS}

Three fan subenvironments were selected for analyses: the middle fan, the lower fan transition sites, and the lower fan. For each subenvironment we first review the acoustic facies units and discuss inferred depositional environment and lithologies; then the general lithologies are compared with the acoustic facies; last, where possible, specific reflectors are compared with specific lithologic boundaries. Although the same acoustic facies are used throughout this study, the units are only generally correlatable between the middle and lower fan.

\section{Middle Fan Acoustic Facies}

Kastens and Shor (1985) distinguished six acoustic units and constructed an acoustic facies map of the midfan meander area (Fig. 2), from which they interpret litholo- 
gies and depositional processes. We use their classification and map boundaries, but apply different names to some of their acoustic facies to facilitate comparison between the different fan subenvironments and to delete morphological interpretation from the acoustic facies names. The units are upper transparent $\left(\mathrm{A}_{1}\right)$, lower transparent $\left(A_{2}\right)$, irregular transparent $\left(A_{3}\right)$, multiple reflector (B), diffuse prolonged (C), and hummocky (D) (Fig. 2).

The transparent units $\left(\mathrm{A}_{1,2}\right)$ are generally restricted to the axis of the channel (see Figs. 5A, B, and 4A). The upper transparent unit $\left(A_{1}\right)$ ranges from less than 30 to more than $50 \mathrm{~m}$ in thickness and is separated from the lower transparent unit $\left(\mathrm{A}_{2}\right)$ by a strong, concave-upward reflector. Although not always visible in the profiles over the center of the channel on the lower energy $3.5-\mathrm{kHz}$ profiles (see Figs. 5A, B, and 4), this boundary is visible in the water-gun profiles (see Stelting et al., this volume). Locally, the transparent unit is also present in topographic depressions adjacent to the channel. A 5- to 10-m-thick, irregular transparent unit $\left(\mathrm{A}_{3}\right)$, which is dominantly acoustically transparent with a patchy, irregular surface reflectivity or with a single diffuse reflector locally, is also present. This unit $\left(\mathrm{A}_{3}\right)$ is widely distributed over the levees (see Figs. 5B, 4, and 7).

The multiple reflector unit (B) consists of 15 to $25 \mathrm{~m}$ of parallel reflectors and occurs primarily along the channel margins (Fig. 3). In some areas it is truncated at the seafloor or buried by the transparent units $\left(A_{1}\right.$ and $\left.A_{2}\right)$. The diffuse-prolonged unit $(C)$ forms the levees and outcrops at the elevated levee crests (see Fig. 5B). In some of the profiles, broad reflectors can be distinguished in this unit away from the channel. The hummocky unit consists of multiple overlapping hyperbolae and covers the northeast slope of the levee (see Fig. 6A).

Lithology and depositional environment of these six acoustic units have been interpreted by Kastens and Shor (1985). The diffuse-prolonged unit (C) is interpreted as consisting of coarser sediment, deposited by high-velocity turbidity currents. The multiple-reflector unit (B) is thought to consist of hemipelagic deposits or finegrained, overbank deposits from lower energy turbidity currents that only slightly modified the channel morphology. The transparent units $\left(\mathrm{A}_{1,2}\right)$ are thought to consist of homogeneous muds deposited by a debris flow, whereas the irregular transparent unit $\left(\mathrm{A}_{3}\right)$ is interpreted as either an eroded remnant of Unit B and/or a thin Unit A. The hummocky unit (D) is interpreted as a slump deposit consisting of small lithified or semiconsolidated blocks that is part of the slump previously mapped by Walker and Massingill (1970).

\section{Middle-Fan Drilling Results}

The four middle-fan drill sites were selected (1) to determine the sedimentary facies formed during channel deposition and (2) to test the hypothesis of channel meandering, which says that the channel shifts its position by erosion of the concave banks and deposition along the convex banks of the bends. Under ideal conditions, the meandering stream will migrate downstream and the amount of bending (sinuosity) will increase. Two sites
(621 and 622) are located in the thalweg and on the inner (concave) side of a channel bend, respectively, and two sites (617 and 620) are located outside of the channel (Figs. 1A, B, 2 and 4). Site 616 is located $144 \mathrm{~km}$ east of the channel in the area interpreted as a slump feature by Walker and Massingill (1970). All six of the acoustic units defined in this region of the fan were penetrated at these midfan sites.

\section{Site 621}

The upper $50 \mathrm{~m}$ at Site 621 consists primarily of a dark gray to olive gray, visually nearly structureless massively bedded mud with rare very thin silt laminae (Site 621 chapter, this volume). X-radiographs of core slabs show poorly defined thin graded silty clays and clays with a variety of high-density inclusions (Roberts and Thayer, 1985). Core recovery is good, averaging $80 \%$. Between 10 and $50 \mathrm{~m}$ sub-bottom, the cored sediment is highly disturbed, probably as a result of gas expansion during recovery. High-resolution $(3.5-4.5 \mathrm{kHz})$ profiles show that the channel is filled with at least $40 \mathrm{~m}$ of acoustically transparent material (Fig. 5A). A reflector between the upper and lower transparent acoustic units fades out before reaching the location of Site 621 (Fig. 5A, B). If this reflector is extrapolated channelward or measured from a presumably correlative reflector on the low-frequency water gun seismic profiles (Stelting et al., this volume), it is about $35 \mathrm{~m}$ sub-bottom depth at the drill site.

Two explanations for this reflector are possible from examination of the core near this interval: (1) gas, as shown in the gas sample from about $35 \mathrm{~m}$ sub-bottom, in Section 621-5-2, which contains the highest methane value recorded at this site or (2) a lithologic change, which occurs at $38.5 \mathrm{~m}$ sub-bottom with a sharp contact between an upper thin (10-cm-thick) black mud and a 24-cm-thick, dark olive gray mottled, and probably bioturbated mud (Fig. 5C). Both the methane content and bioturbation suggest high biological activity in the area and could have contributed to the formation of this reflector.

\section{Site 622}

Core recovery in the upper $50 \mathrm{~m}$ at Site 622 was poorer than at Site 621 , averaging only about $52 \%$. Similar to Site 621 , the recovered sediments are dark gray and olive gray, relatively structureless muds, with rare thin silt laminae (Site 622 chapter, this volume). Poorly defined graded silt laminations, scattered diagenetic inclusions, and microfractures are observed in x-radiography slabs from this core (see Coleman et al., this volume, Roberts and Thayer, 1985). This site is slightly closer to the levee and farther from the channel thalweg than Site 621 (Fig. 4). It is located within a transition between the transparent unit (A) and the diffuse-prolonged unit (C) where several weak, steeply dipping reflectors extend from the channel levee toward the channel floor (Fig. 6A). Two of these dipping reflectors were apparently penetrated at Site 622 at depths of $12 \mathrm{~m}(15 \mathrm{~ms})$ and $28 \mathrm{~m}$ (37 ms) sub-bottom. Sediments were not recovered at the depth interval of the upper reflector. Near $28 \mathrm{~m}$ sub- 

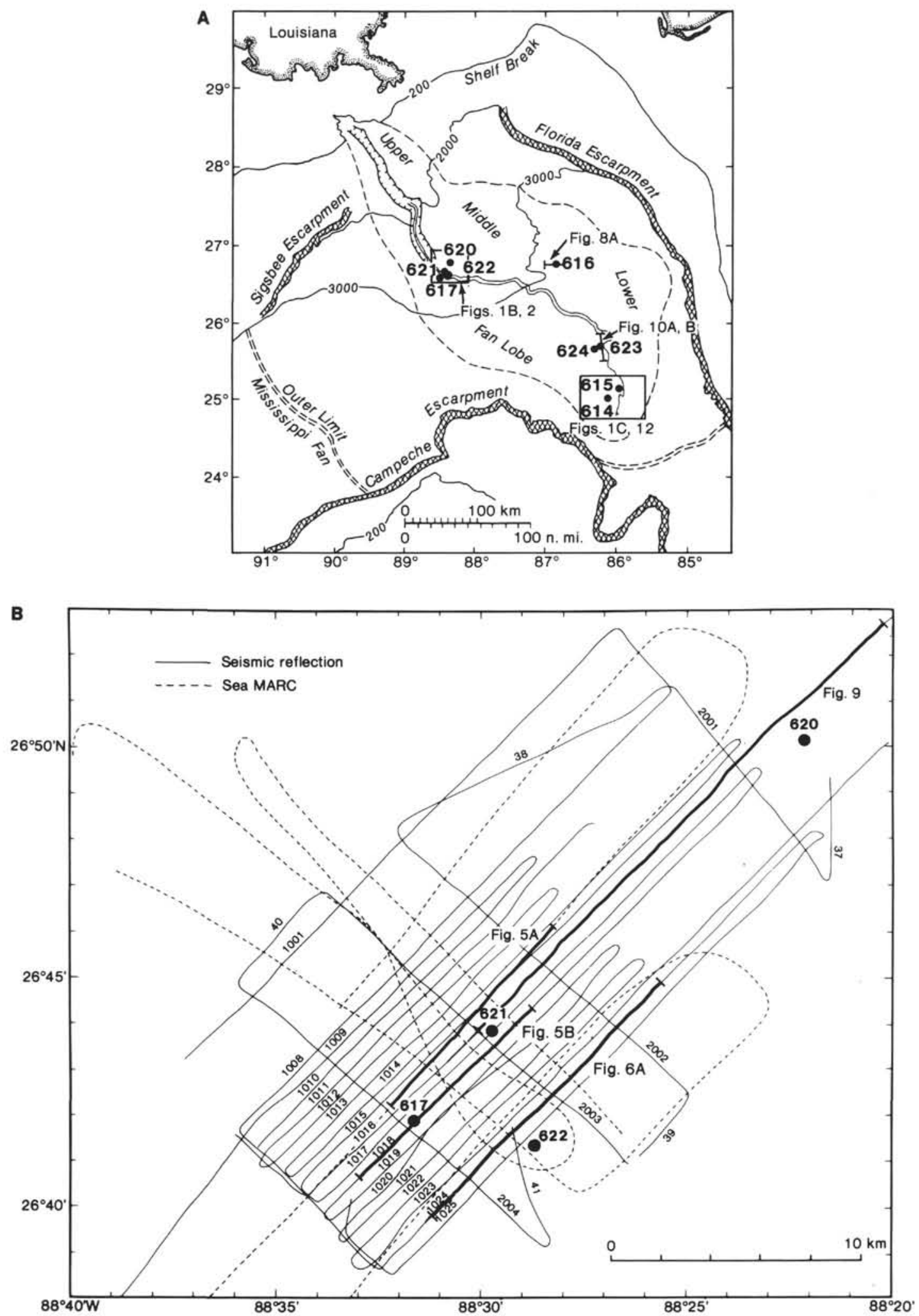

Figure 1. A. Standard Leg 96 location map, showing fan channel, the 9 DSDP middle and lower Mississippi Fan sites, location of Figures 1B, 1C, 2, and 12, and seismic tracks for Figures 8A, 10A, and 10B. B. Map showing midfan site-survey shiptracks, Sea MARC I tracks, DSDP sites, and location of Figures 5A, 5B, 6A, and 9. C. Map showing lower-fan site-survey shiptracks, Sea MARC I tracks, DSDP sites, and location of Figures 13A and 14A. 
C

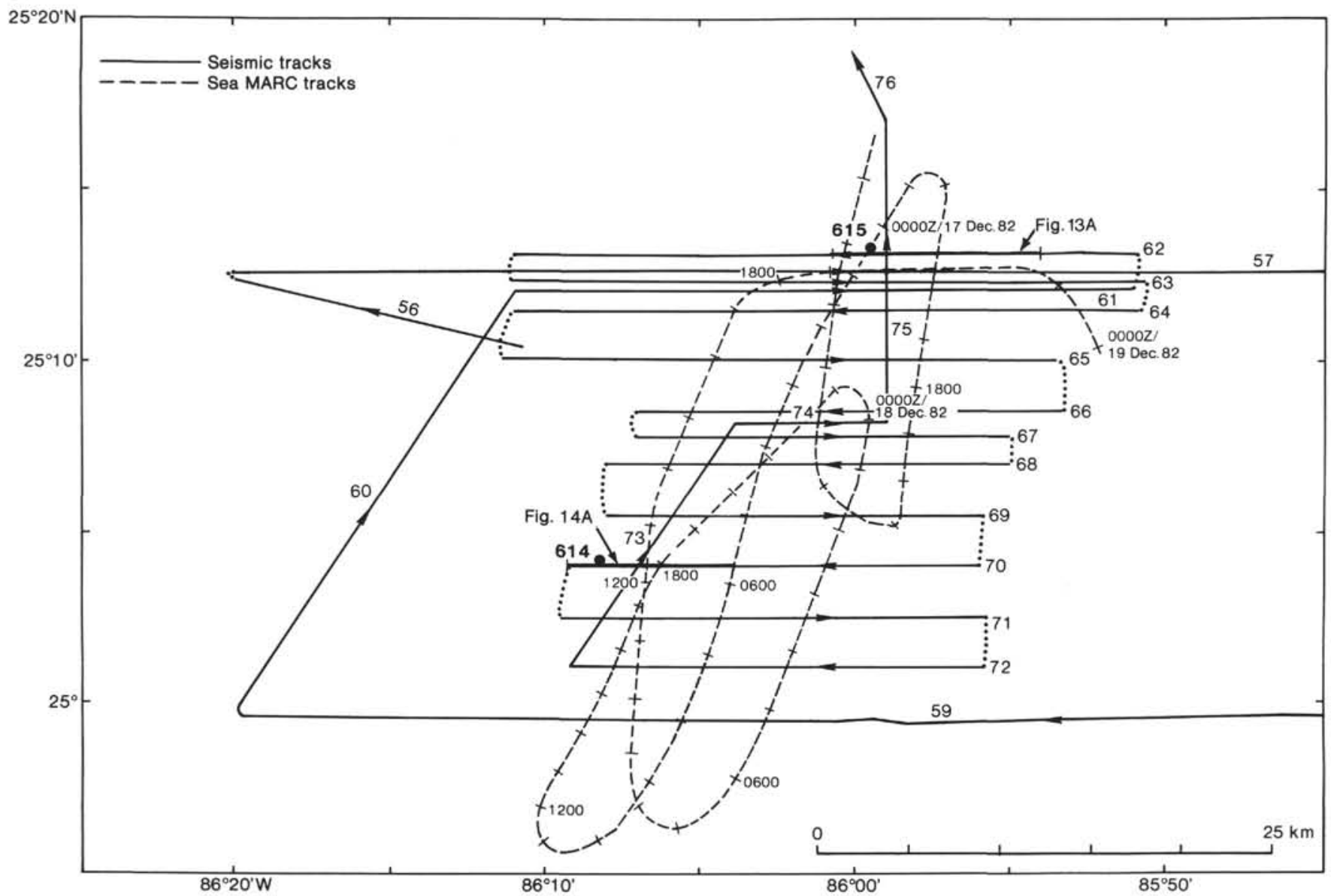

Figure 1 (continued).

Table 1. Calculated and measured sonic velocities $(\mathrm{km} / \mathrm{s})$ in upper 50 m of sediment. ${ }^{a}$

\begin{tabular}{ccccccc}
\hline $\begin{array}{c}\text { Sub-bottom } \\
\text { depth }^{\mathrm{b}} \\
(\mathrm{m})\end{array}$ & $\begin{array}{c}\text { Calculated } \\
\text { velocity } \\
(\mathrm{km} / \mathrm{s})\end{array}$ & $\begin{array}{c}\text { Hydro- } \\
\text { pinger }^{\mathrm{d}}\end{array}$ & Site 615 & Site 617 & Site 620 & Site 622 \\
\hline 0 & 1.524 & 1.55 & $1.47-1.48$ & & $1.43-2.01$ & $1.56-1.64$ \\
10 & 1.532 & 1.55 & $1.45-1.49$ & $1.40-1.44$ & $1.43-1.56$ & \\
20 & 1.541 & 1.55 & & $1.42-1.49$ & $1.42-1.44$ & \\
30 & 1.549 & 1.55 & $1.50-1.53$ & $1.46-1.50$ & $1.46-1.55$ & \\
40 & 1.557 & 1.54 & 1.51 & 1.50 & & \\
50 & 1.565 & 1.78 & $1.51-1.53$ & $1.45-1.53$ & $1.46-1.49$ & $1.37-1.61$ \\
\hline
\end{tabular}

a Range of shipboard measurements for each interval (site chapters, this volume).

${ }^{\mathrm{b}}$ Site depths are $\pm 5 \mathrm{~m}$.

c $V=0.762+0.00032 \times R ; R=0.762+\underline{(0.7622+4.00016 \times D)-2}$

d Flood and Bryan (1983), runs 2-4, middle fan near an area where Unit B overlies Unit C, at $26^{\circ} 45.5^{\prime} \mathrm{N}, 88^{\circ} 31.70^{\prime} \mathrm{W}$.

bottom (Fig. 6B), there are weakly color-banded sediments with irregular dark patches, and we tentatively interpret the patches and color banding to contribute to the formation of the steeply dipping reflector.

\section{Site 617}

Site 617 is on the western levee on the concave side of the channel bend (Fig. 4) in an area of ridge and swale topography (Kastens and Shor, 1985) about $2.5 \mathrm{~km}$ west of the levee crest and $4.75 \mathrm{~km}$ west of the channel thalweg. The site penetrated a section exhibiting multiple re- flectors (Unit B) overlying Unit $\mathrm{C}$ on the $3.5-\mathrm{kHz}$ profile (Figs. 5B, 6A).

Sediment recovery in the upper $50 \mathrm{~m}$ of Site 617 varied between 80 and $100 \%$. The upper $18 \mathrm{~m}$ of sediment recovered at Site 617 consists of color-banded muds with very thin silt laminae. The color bands range from reddish brown to very dark greyish brown or black. The black layers are generally mottled, which may be a result of bioturbation. Below $18 \mathrm{~m}$ the number of silt laminations increases, but they are never very abundant.

Table 2 lists the depth to the reflectors and observed lithologic character that may have caused or contributed to their occurrence. The only possible correlations occur between a thin graded silt layer at $15.2 \mathrm{~m}$ sub-bottom (Fig. 7) and a reflector at $13 \mathrm{~m}$, and the steepening inclination of the silt layers at $21.7 \mathrm{~m}$ sub-bottom and the diffuse-prolonged reflector at $22 \mathrm{~m}$.

\section{Sites 620 and 616}

Site 620 is located about $18.3 \mathrm{~km}$ northeast of the center of the midfan channel; Site 616 is $144.5 \mathrm{~km}$ farther to the east (Fig. 1A). Profiles from both sites exhibit similar acoustic signatures, consisting of hummocky surface returns with few or no sub-bottom reflectors (Figs. 8A and 9). The hummocky surface is more pronounced at Site 620 than at Site 616 . 


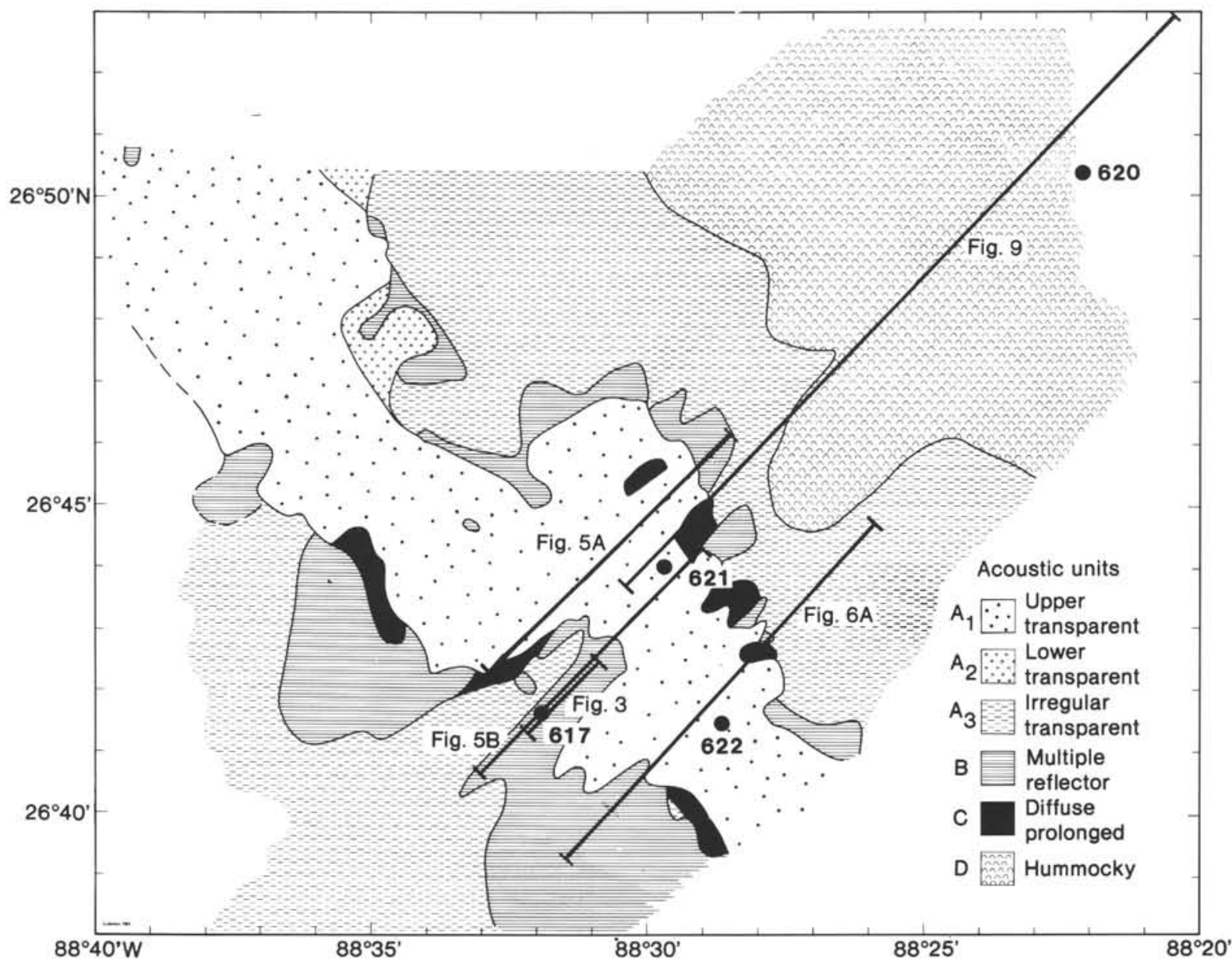

Figure 2. Modified acoustic facies map of the middle Mississippi Fan survey area (from Kastens and Shor, 1985, figure 10, with permission), including location of DSDP Sites 617, 620, 621, and 622 and Figures 3, 5A, 5B, 6A, and 9.

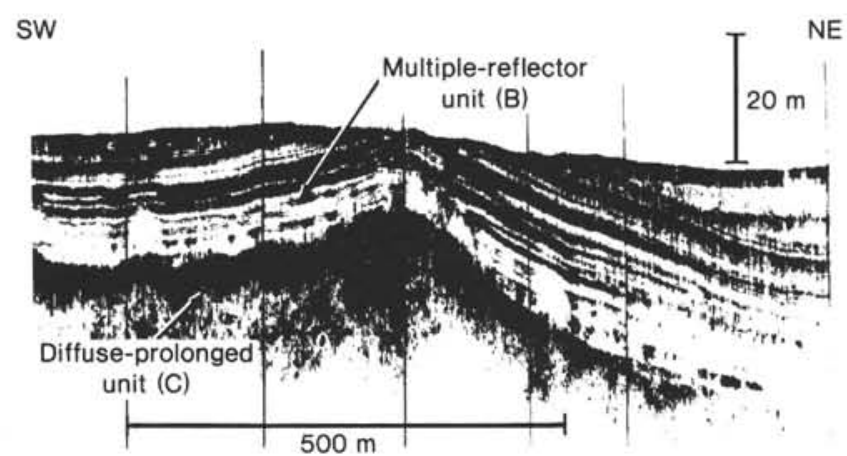

Figure 3. 3.5-kHz profile at Site 617 from Racal-Decca, EDO-Western deep-tow survey (from Prior et al., 1983, figure 3). This profile was used to measure the reflector depths given in Table 2. Location of profile shown in Figure 2.

Site 620 was rotary drilled, resulting in extensive core disturbance. Sediment recovery in the upper $50 \mathrm{~m}$ of the site was variable, ranging between 29 and $100 \%$, but averaging only $50 \%$. Below a 20 -cm-thick muddy ooze at the sediment/water interface, the section consists of homogeneous color-banded clays and silt-laminated muds. The silt laminae are contorted or occur in discontinuous blebs, but these are probably coring disturbances and are probably not primary (Site 620 chapter, this volume).

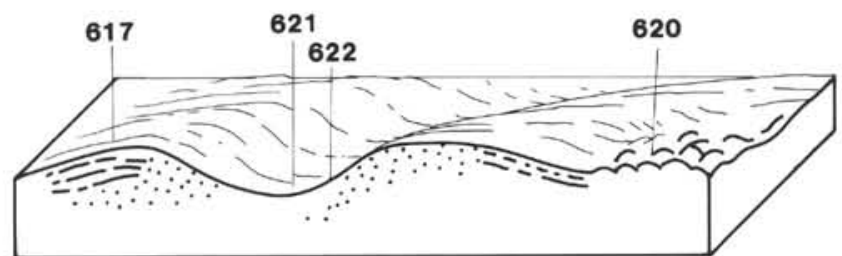

Figure 4. Schematic diagram showing location of middle-fan sites with respect to acoustic facies units and morphology.

Recovery in the upper $50 \mathrm{~m}$ at Site 616 was excellent, varying between 90 and $100 \%$. The sediment consists of grayish brown mud with thin to very thin silt laminae that occur with frequencies as high as $\mathbf{3 0 0}$ laminae per meter. Some of the thicker silt layers are graded with scoured bases. The laminae dip varies from flat to almost vertical, but most dip less than $45^{\circ}$ (Fig. 8B). The variability of dip and presence of horizontal laminae within a single core suggests that the dips are a primary sedimentary feature and not an artifact of coring disturbance.

The acoustic units observed on the $3.5-\mathrm{kHz}$ profiles from both of these sites have been interpreted as slump or debris-flow deposits, or (less likely) sandy material at the seafloor (Normark et al., 1979; Damuth, 1980; Embley, 1980). Coarse-grained sediment however, was not 
A
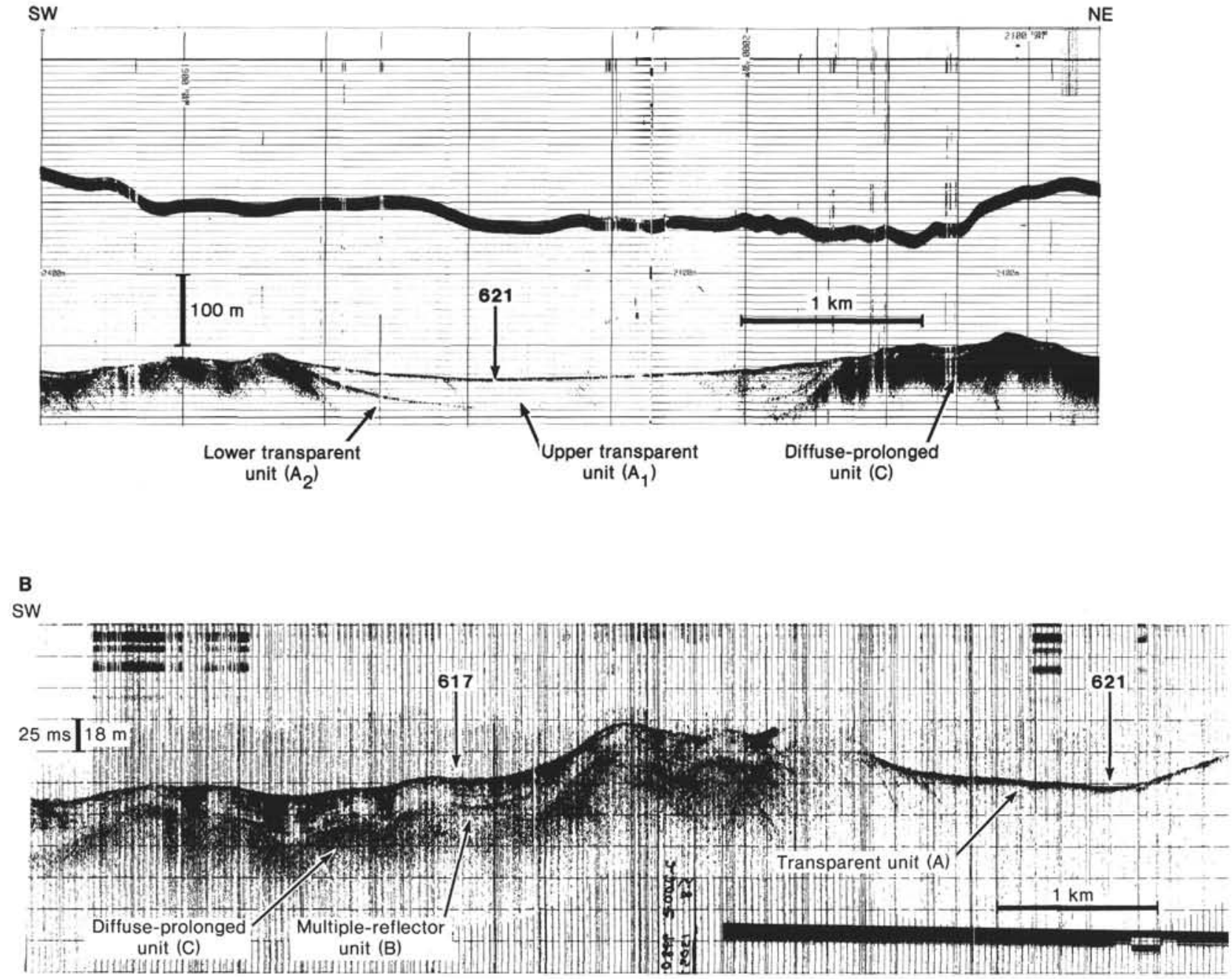

C

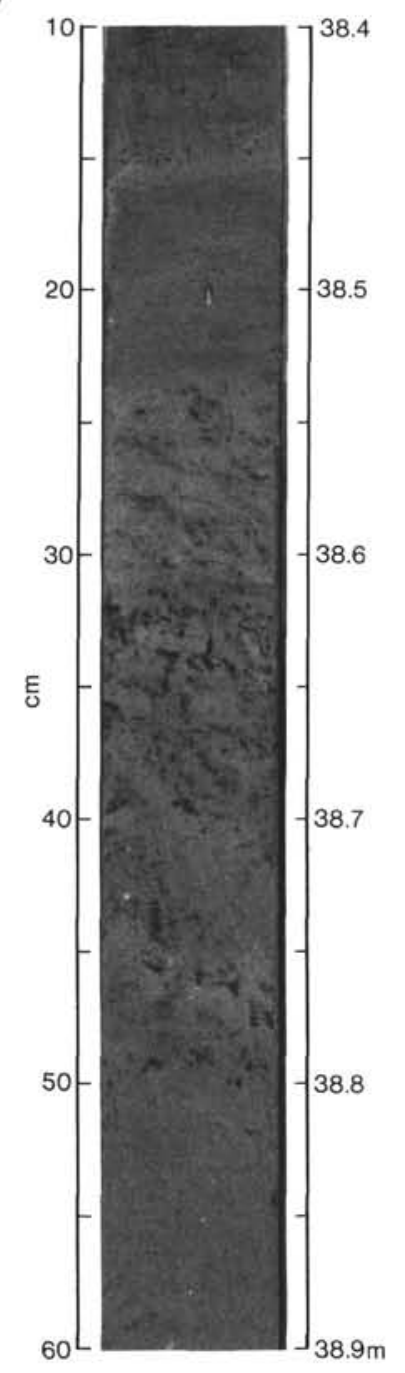

Figure 5. A. 4.5-kHz profile from Sea MARC I near Site 621. B. 3.5-kHz profile from site-survey cruise (Conrad 23-12, Line 1018) showing locations of Sites 621 and 617. C. Photograph (Sample 621-5-5, 10-60 cm, 38.4-38.9 m sub-bottom) of boundary ( $38.5 \mathrm{~m}$ sub-bottom) between black mud and mottled (probably by bioturbation) dark gray mud near the depth of an acoustic reflector. Location of profiles shown in Figures 1B and 2. 

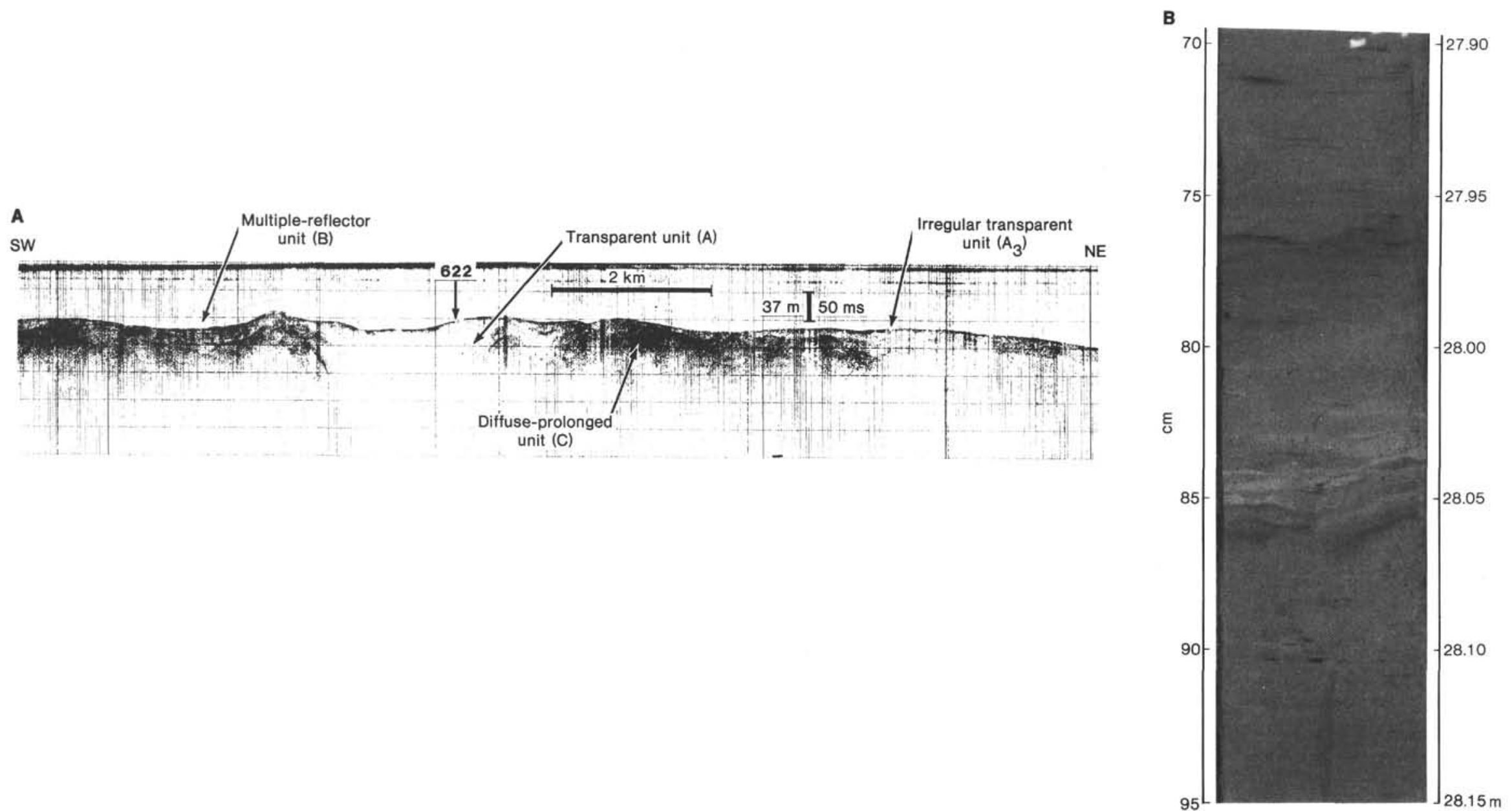

Figure 6. A. 3.5-kHz profile from site-survey cruise (Conrad 23-12, Line 1024) showing location of Site 622. B. Photograph (Sample 622-4-4, 70-95 cm, 27.9-28.15 m sub-bottom) of a weakly color-banded sediment with irregular dark patches. 
Table 2. Depth to sub-bottom reflectors at Site 617 and assumed corresponding lithologic contacts. ${ }^{\mathrm{a}}$

\begin{tabular}{ccccc}
\hline \multicolumn{2}{c}{ Reflectors } & & \multicolumn{2}{c}{ Lithologic contacts } \\
\cline { 1 - 1 } $\begin{array}{c}\text { Sub-bottom } \\
\text { depth } \\
(\mathrm{ms})\end{array}$ & $\begin{array}{c}\text { Sub-bottom } \\
\text { depth } \\
(\mathrm{m})\end{array}$ & & $\begin{array}{c}\text { Sub-bottom } \\
\text { depth } \\
(\mathrm{m})\end{array}$ & \multicolumn{1}{c}{ Comments } \\
\hline 7 & 5 & & 5.4 & $\begin{array}{l}\text { 6-cm graded silt layer } \\
\text { 2-cm silt layer }\end{array}$ \\
15 & 11.5 & & 6.2 & \\
17 & 13 & & 14.2 & $\begin{array}{l}\text { 6 thin silt laminae } \\
\text { 2-cm graded silt layer } \\
\text { (Fig. 7) }\end{array}$ \\
& & 15.2 & $\begin{array}{l}\text { Inclination steepens } \\
\text { Graded silt and sand } \\
\text { beds }\end{array}$ \\
41 & 22 & 21.7 & 23.7 & \\
\hline
\end{tabular}

${ }^{\text {a }}$ From EDO deep-tow 3.5-kHz profile shown in Figure 3.

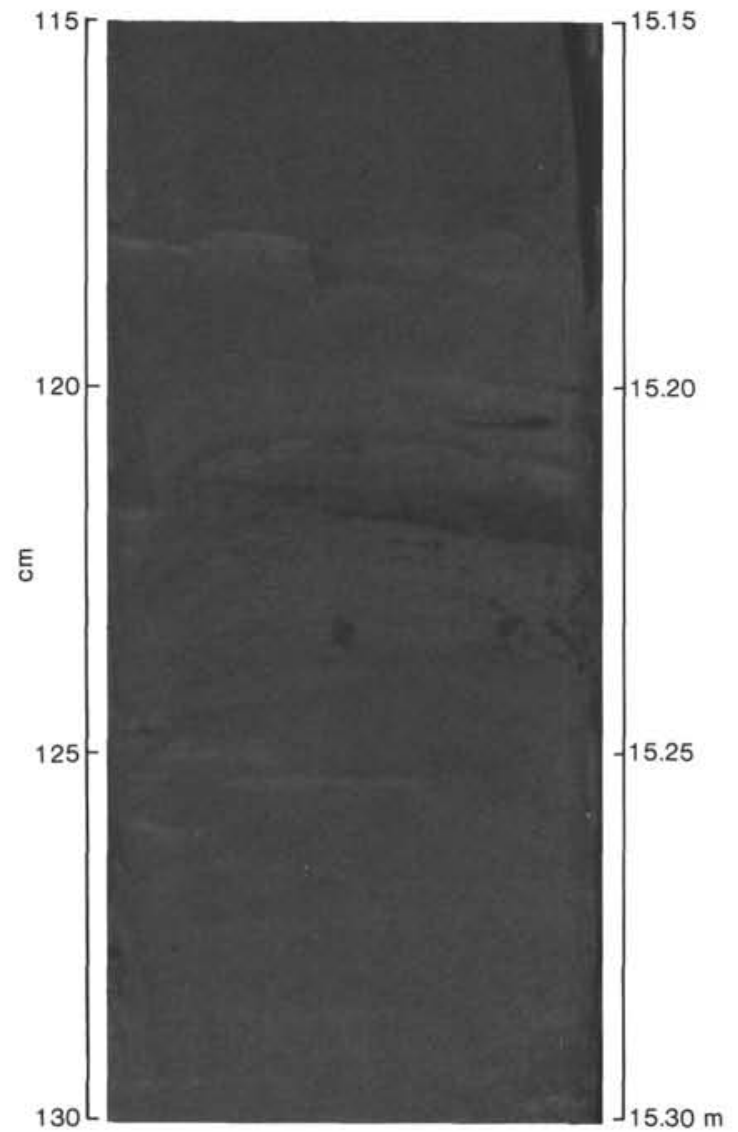

Figure 7. Photograph (Sample 617-2-5, 115-130 cm, 15.15-15.30 m sub-bottom) showing very thin layer of graded silt ( $15.2 \mathrm{~m}$ sub-bottom).

common at either site. Interpretation of the sediment recovered at Site 620 is problematic because most of the bed disruption appears to result from coring disturbance. Site 616 , in contrast, has abundant thin silt layers dipping at different angles within discrete sections of the core (Fig. 8B), probably a result of slumping. Sound traversing through the variably dipping layer (especially steeply) would not provide extensive reflecting surfaces, and acoustic interference patterns would be expected.

\section{Lower-Fan Transition Acoustic Facies}

Sites 623 and 624 lie within the upper part of the lower fan at $3180 \mathrm{~m}$ water depth. These two sites lie about $2 \mathrm{~km}$ downfan from a filled channel that is difficult to identify (Fig. 10A, B) and $55 \mathrm{~km}$ upfan (north-northwest) from the lower-fan sites (Fig. 1A). Four acousticfacies units are present in this area: a transparent unit (A), a multiple-reflector unit (B), a diffuse-prolonged unit $(C)$, and a hummocky unit $(D$, not shown on profile).

The transparent unit (A) occurs as both (1) a 5- to 15-m-thick layer overlying parts of the diffuse-prolonged unit (C) (Fig. 10A) and (2) a unit of indeterminate thickness that fills depressions (Fig. 10B). The multiple-reflector unit (B) consists of short, irregular, subparallel reflectors that form some levee-overbank deposits. The diffuse-prolonged unit $(\mathrm{C})$ has a variable intensity, and its penetration ranges from 10 to $40 \mathrm{~m}$. Unit $\mathrm{C}$ forms the channel margins and occurs as thin, seafloor-paralleling lobes (Fig. 10A, B).

The dominance of Unit $\mathrm{C}$ in this area suggests a high percentage of coarse sediment and/or rough surfaces (Damuth, 1975, 1980; Normark and Gutmacher, 1983/ 84; Normark et al., 1983/84). The variable intensity of Unit $\mathrm{C}$ deposits, becoming weaker and thinner downfan or away from the channel, indicates that the percentage of coarse material within the deposit changes, even over the distance of a kilometer. Unit C most commonly abuts the transparent unit (Fig. 10A).

Lying within former topographic lows, the transparent unit (A) probably consists of fine-grained, homogeneous sediment, possibly emplaced as a debris flow. The few, small areas of the multiple-reflector unit (B) may indicate remanent levees and distal turbidite deposits. The lack of multiple-reflector units in this channelized area suggests that most of the sediment consists of coarse material, probably with a rough surface, and possibly bedforms.

\section{Lower-Fan Transition Drilling Results}

Site 623 lies $0.5 \mathrm{~km}$ west of the $3.5-\mathrm{kHz}$ profile of Figure 10A within a region of acoustic Unit C. Site 624 lies about $2.5 \mathrm{~km}$ west of the deep-towed $4.5-\mathrm{kHz}$ profile (Fig. 10B), within a region of less intensely reflecting Unit $C$. The acoustic facies units at these two sites appear similar to areas on other deep-sea fans with a high sand content, possibly with a higher sand content at Site 623 because of the higher intensity of Unit C (Damuth, 1975, 1980; Normark and Gutmacher, 1983/84; Normark et al., 1983/84).

Core recovery in the upper $50 \mathrm{~m}$ at both sites was relatively good, averaging about $85 \%$. Both sites are dominated by laminated to thinly bedded silts in a clay matrix. Grading is observed in some of the silts; as many as 22 laminations are present in a 6-cm interval (Fig. 11A, B). The percentage of silt laminations varies downhole, and shows a significant increase below $3 \mathrm{~m}$ at Site 623 and below $7.8 \mathrm{~m}$ at Site 624 . The finely laminated sedi- 
A

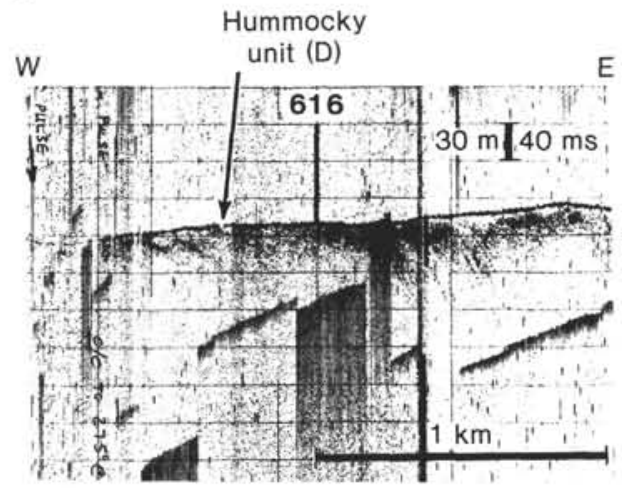

B

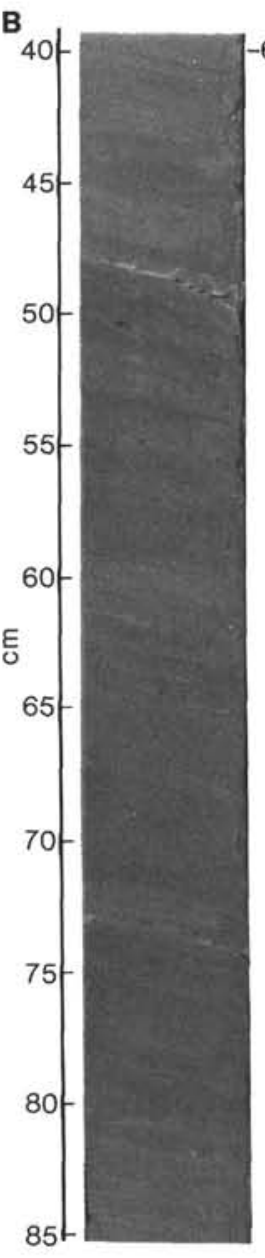

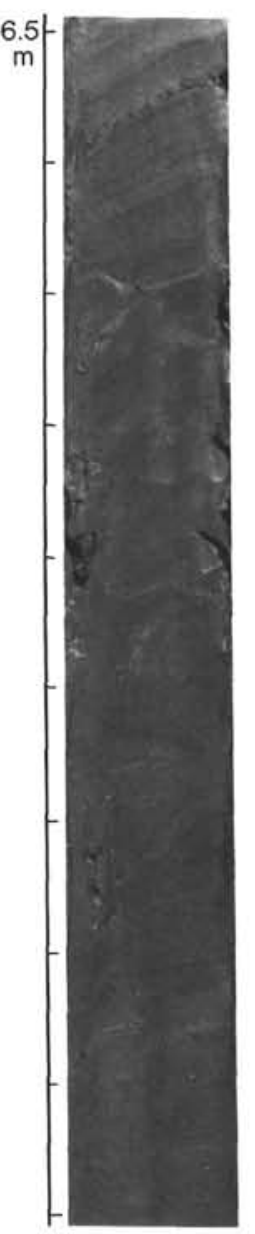
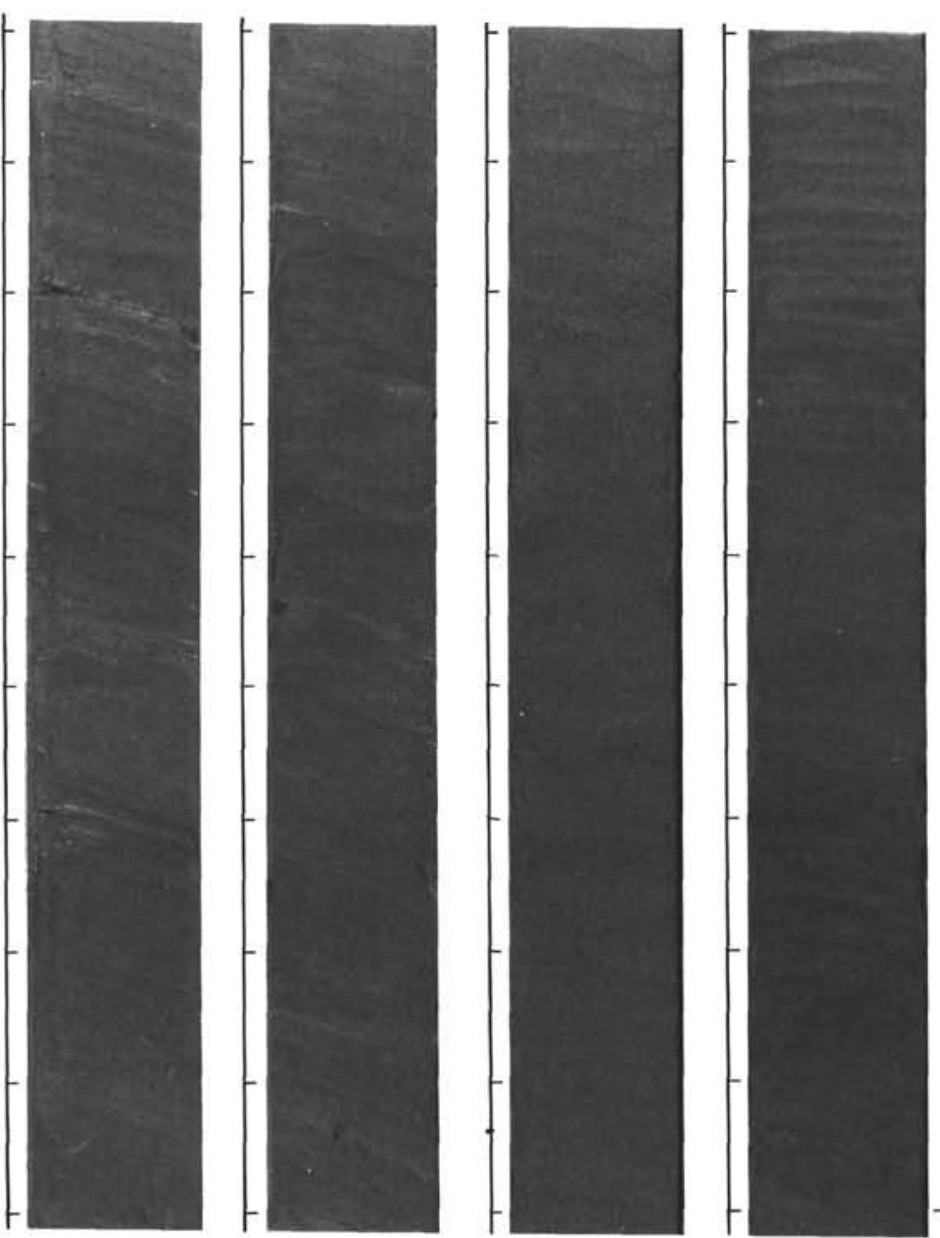

$-14.4 \mathrm{~m}$ 


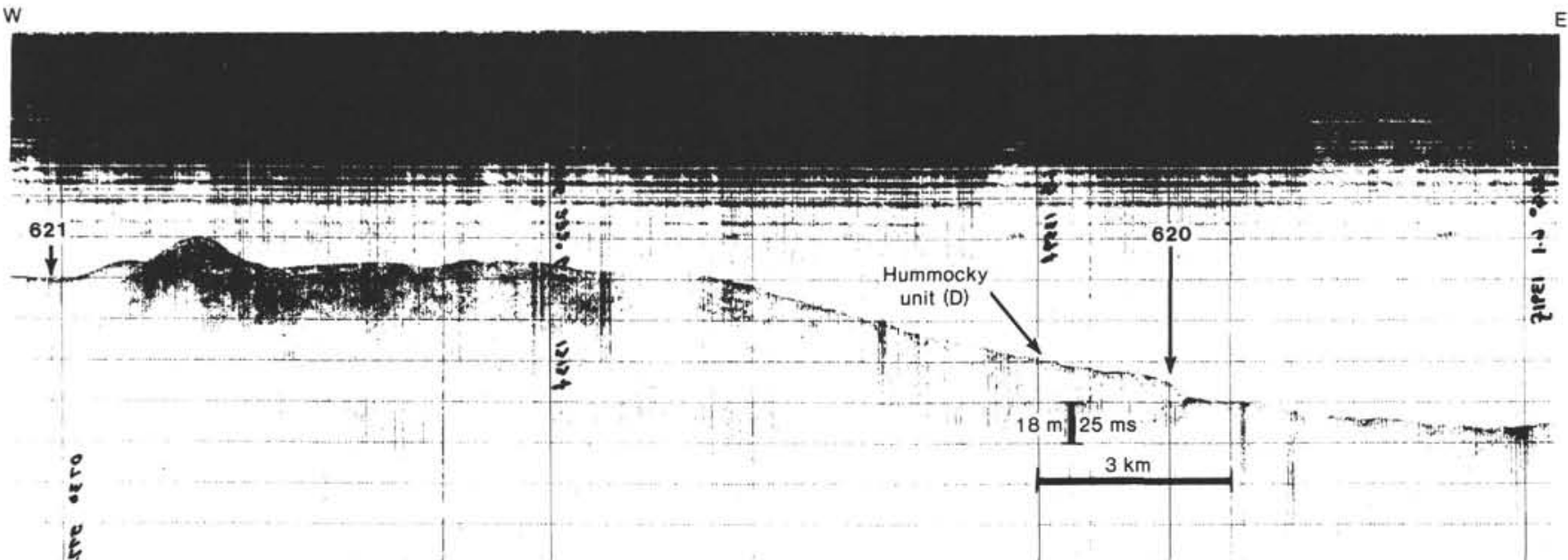

Figure 9. 3.5-kHz profile from site-survey cruise (Conrad 23-12, Line 1016) 1 km north of Site 620. Location of profile shown in Figures $1 \mathrm{~B}$ and 2.

A

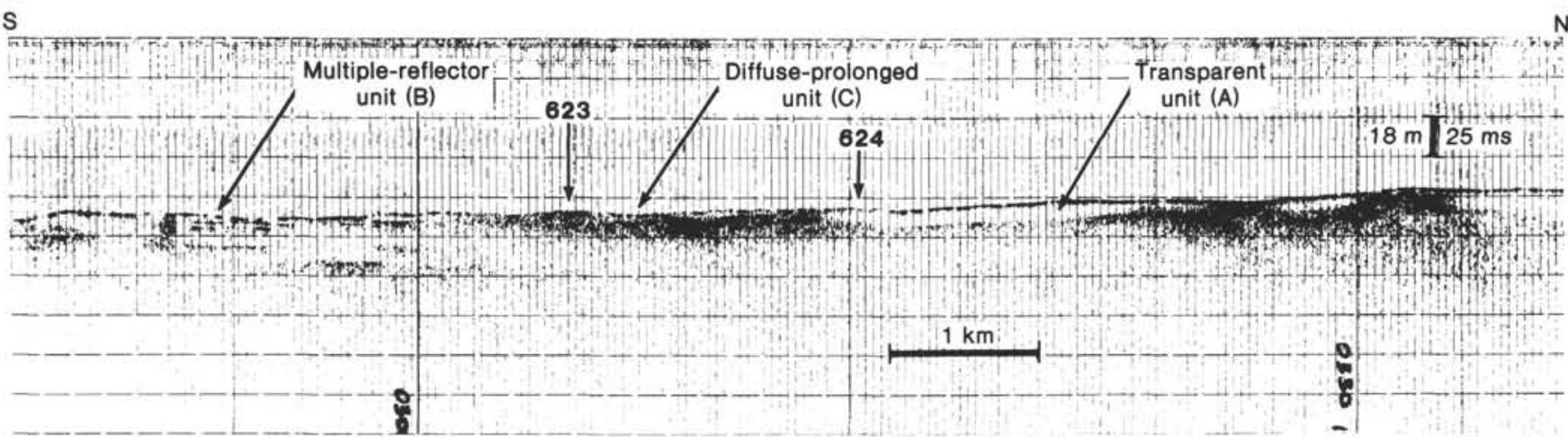

B

$\mathrm{S}$

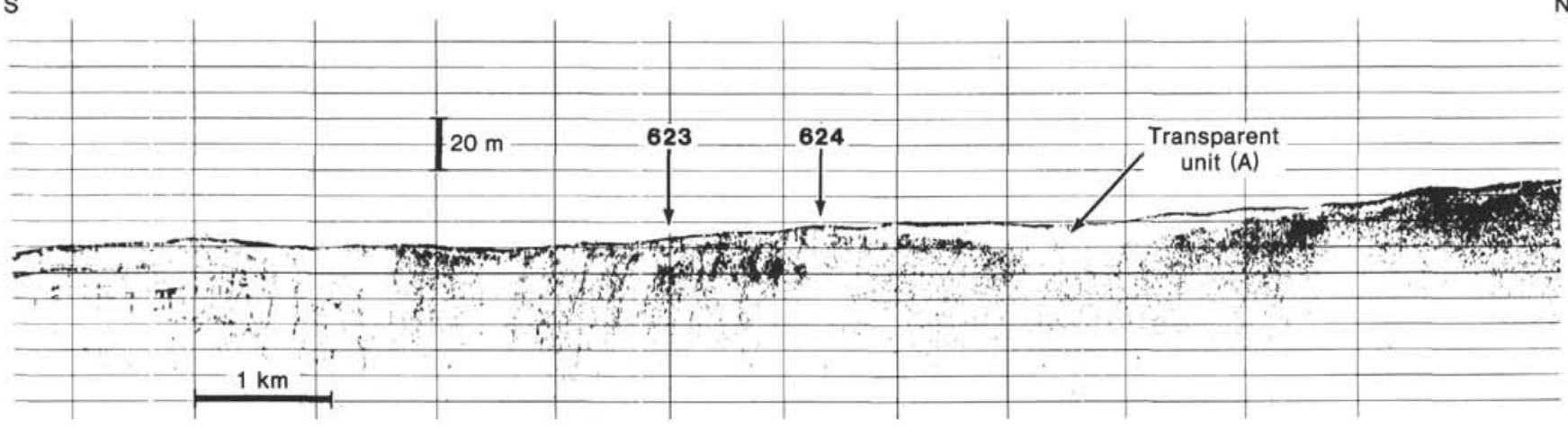

Figure 10. A. 3.5-kHz profile from site-survey cruise (Conrad 23-12, Line 79), near Sites 623 and 624. B. Sea MARC I, 4.5-kHz deep-towed profile (Conrad 23-12) near Sites 623 and 624. Location of profiles shown in Figure 1A.

ments recovered at these sites are deposits that would be expected from both overbank and distal turbidites.

The percentage of coarser sediment is greater at Site 623 than at Site 624. The sediments, however, are neither as coarse nor as thick as would be expected from the intensity of Unit C, suggesting that the reflector is caused by either the interference of many thin layers or a rough surface.

\section{Lower-Fan Acoustic Facies}

Three acoustic facies units are recognized on the lower fan: transparent (A), multiple reflectors (B), and diffuse prolonged $(\mathrm{C})$. They are mapped from $3.5-\mathrm{kHz}$ profiles collected within a $1250-\mathrm{km}^{2}$ area that was surveyed with a 1- to 2-km line spacing during the site-survey cruise (Fig. 1C). 


\section{S. O'CONNELL, W. R. NORMARK}
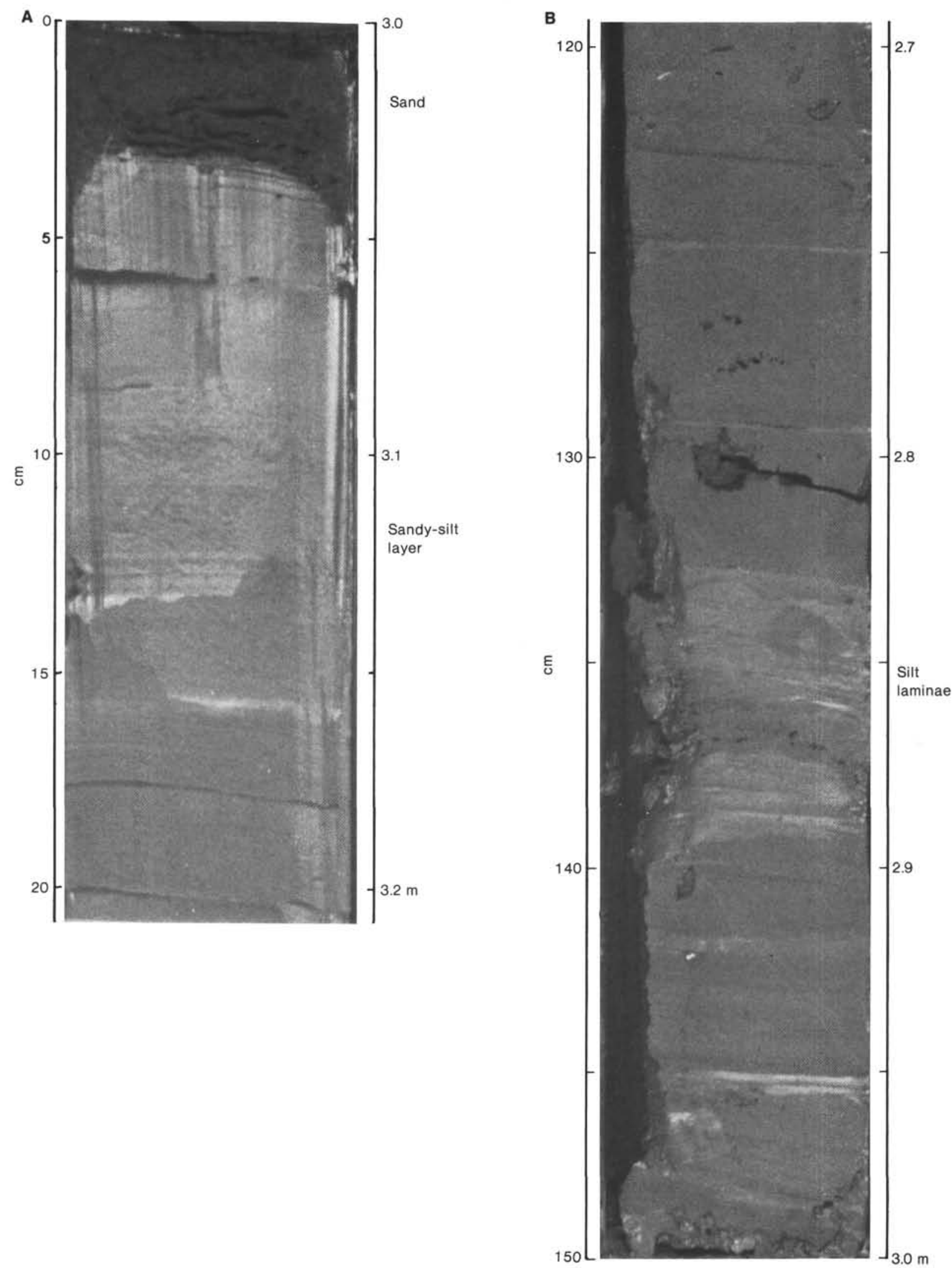

Figure 11. A. Photograph of two separate 1-cm-thick sandy-silt layers at $3 \mathrm{~m}$ sub-bottom (Sample 623-1-3, 0-20 cm, 3.0-3.2 m subbottom). B. Photograph of silt laminae in structureless mud (Sample 624-1-2, 120-150 cm) 2.7-3.0 m sub-bottom. 
Surface distribution of the acoustic units is shown in Figure 12. The western area is dominated by the multiple-reflector unit, whereas the transparent (A) and diffuse-prolonged (C) units are co-dominant in the eastern and central area. The transparent unit emanates from the channel and spreads over the diffuse-prolonged unit, forming a 2- to 10 -m-thick cover over most of the central part of the lower fan study area and 1- to 4-km-wide south to southeast trending lobate deposits.

The channel floor, eastern levee, and most of the central channeled area are characterized by a diffuse-prolonged acoustic return (Unit C) (Fig. 12). On the surface, the transparent unit commonly overlaps the diffuse-prolonged unit, but in the sub-surface the boundary between these two units is usually abrupt.

The western levee and the majority of the lower fan study area, particularly the region west of the lower-fan leveed channel, are characterized by the multiple-reflector units (B). Individual reflectors are spaced 1 to $5 \mathrm{~m}$ apart and can be traced for up to $8 \mathrm{~km}$ along profiles. Depth of penetration in some areas is limited by the system power and deeper reflectors are progressively weaker. In other areas, the reflectors are underlain by a diffuse-prolonged reflector that appears to block further penetration.

Unlike the midfan area, the morphological relationship of these units to each other and the channel is not straightforward. The distribution of acoustic units does not appear to be influenced by the few meters of bathymetric relief. There are, however, several remanent channels in the central area, which on side-looking sonar show varying amounts of surface cover. We speculate that the distribution of acoustic facies units in this area is controlled by the composition and flow dynamics associated with the intertwining remanent channels and deposition of successive layers of sediment in the low relief areas of a channel termination.

\section{Lower-Fan Drilling Results}

Sites 614 and 615 , approximately $22 \mathrm{~km}$ apart, were drilled on the western side of a lower fan channel (Figs. $1 \mathrm{C}$ and 12) to identify the sedimentary character and modes of sediment transport within a lower fan lobe. They were both located within an area with multiple re-

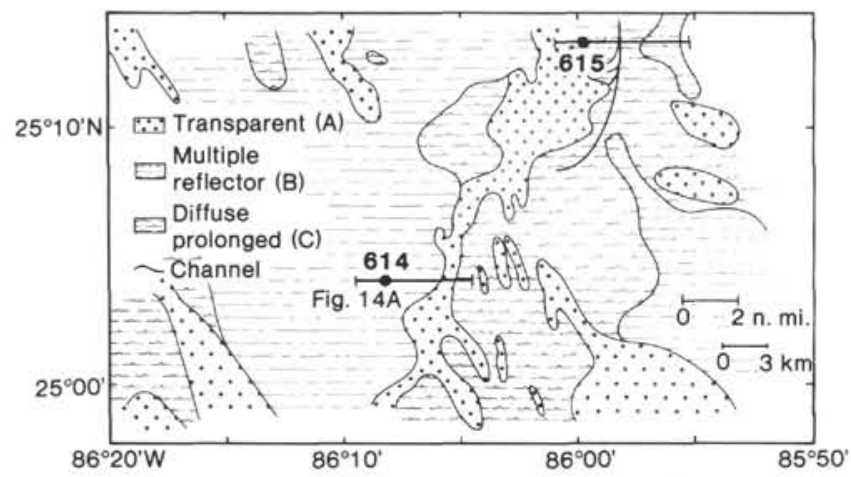

Figure 12. Acoustic facies map of the surface of the lower Mississippi Fan site-survey area, showing the location of channel, DSDP Sites 614 and 615 , and Figures 13A and 14A. flectors at the surface (Unit B), underlain by the diffuseprolonged unit (C) (Figs. 13 and 14).

Thin-bedded turbidites would be expected where multiple reflectors (Unit B) are recorded. Because the reflectors are discontinuous and have variable intensity, the bedded sediments in the lower fan would be expected to be coarser than sediments from the similar acoustic unit (B) in the midfan. Coarser sediment would be expected at the level where Unit $\mathrm{C}$ is encountered.

\section{Site 615}

Site 615 is located about $2 \mathrm{~km}$ from the western levee crest (Fig. 13A) and $10 \mathrm{~km}$ from a topographic high that marks the termination of the eastern levee and the channel. A 3.5-kHz record obtained aboard the Glomar Challenger for Site 615 is shown in Figure 13B. This "profile" was collected during the time when the ship was being positioned over the site and represents less than $200 \mathrm{~m}$ of movement in a north-northeast direction from the acoustic beacon.

Sediment recovery in the upper $50 \mathrm{~m}$ of this site was good and averaged $88 \%$. The sediments recovered at this site consist of multiple silt and sand laminations and beds within a mud matrix.

Table 3 lists depths to all of the reflection horizons seen on the $3.5-\mathrm{kHz}$ record within $40 \mathrm{~m}$ of the acoustic beacon for Site 615 and depths to all of the lithologic contacts observed in the recovered core material. Not all of the reflectors can be resolved clearly because $2-3 \mathrm{~ms}$ is the best resolution of reflector spacing on this record. Furthermore, not all sand/mud contacts are observed as reflectors on the $3.5-\mathrm{kHz}$ record, and several reflectors have no corresponding recognizable lithologic contrast. Nevertheless, it is clear that the extensive, diffuse-prolonged reflector at $20 \mathrm{~ms}(15.4 \mathrm{~m})$ sub-bottom depth is correlatable with the top of a thick sand bed $(15.2 \mathrm{~m}$ sub-bottom) that effectively blocks any deeper acoustic penetration (Fig. 15A). Higher in the section, all sandy horizons greater than $50 \mathrm{~cm}$ in thickness generally correspond to reflection events.

\section{Site 614}

Site 614 is the most distal site drilled on the fan during Leg 96. It is approximately $600 \mathrm{~km}$ from the head of the Mississippi Canyon and in the deepest water (3314 $\mathrm{m})$. The youngest fan lobe in this area is only slightly convex upward and dips seaward with a $<0.1^{\circ}$ gradient.

Similar to the profile for Site 615, the profile in Figure 14B represents oscillatory movement of the ship on a scale of less than $200 \mathrm{~m}$ along a line extending WSW (about $240^{\circ}$ ) from the acoustic beacon. Traveltimes to the various reflectors have been converted to meters. The deepest resolvable reflector occurs at $36 \mathrm{~ms}$, which equals $27.5 \mathrm{~m}$ sub-bottom depth. Table 4 lists the traveltimes and depths at which the reflectors on the $3.5-\mathrm{kHz}$ profile occur and the depth of all major lithologic contracts in the upper $30 \mathrm{~m}$ of the core (Fig. 15B, C).

Sediment recovery was essentially $100 \%$ in the upper $50 \mathrm{~m}$ at Site 614 , the highest of any site drilled during Leg 96. Correlation of the reflectors and lithologic contacts shows that: (1) in the upper part of the hole, above 


\section{A}

W

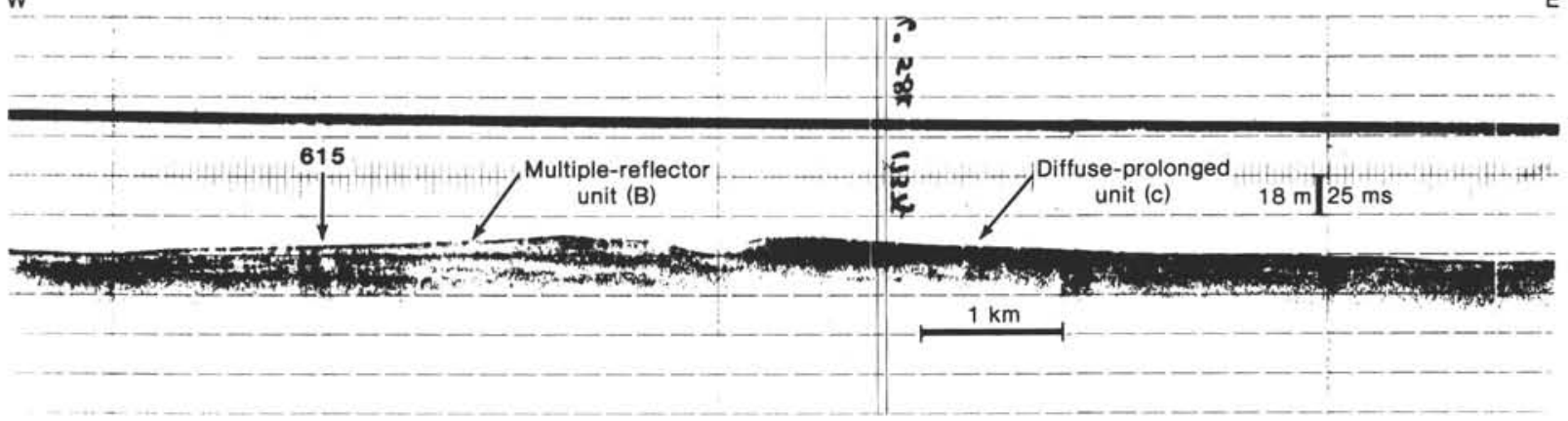

B

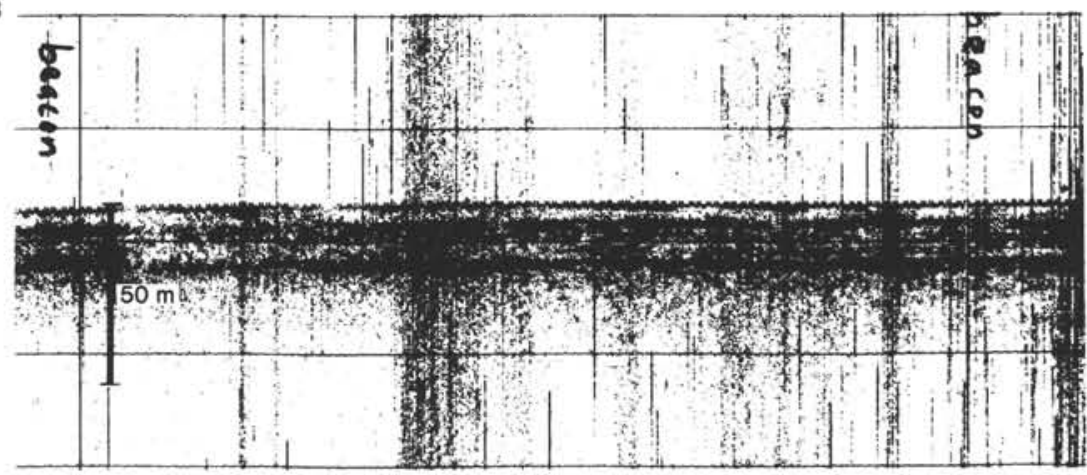

Figure 13. A. 3.5-kHz profile from site survey cruise (Conrad 23-12, Line 62) near Site 615. Location of profile shown in Figures $1 \mathrm{C}$ and 12. B. $3.5-\mathrm{kHz}$ profile from the Glomar Challenger while positioning over beacon. The profile represents less than $200 \mathrm{~m}$ of movement, and these data were used to measure the reflector depths presented in Table 3.
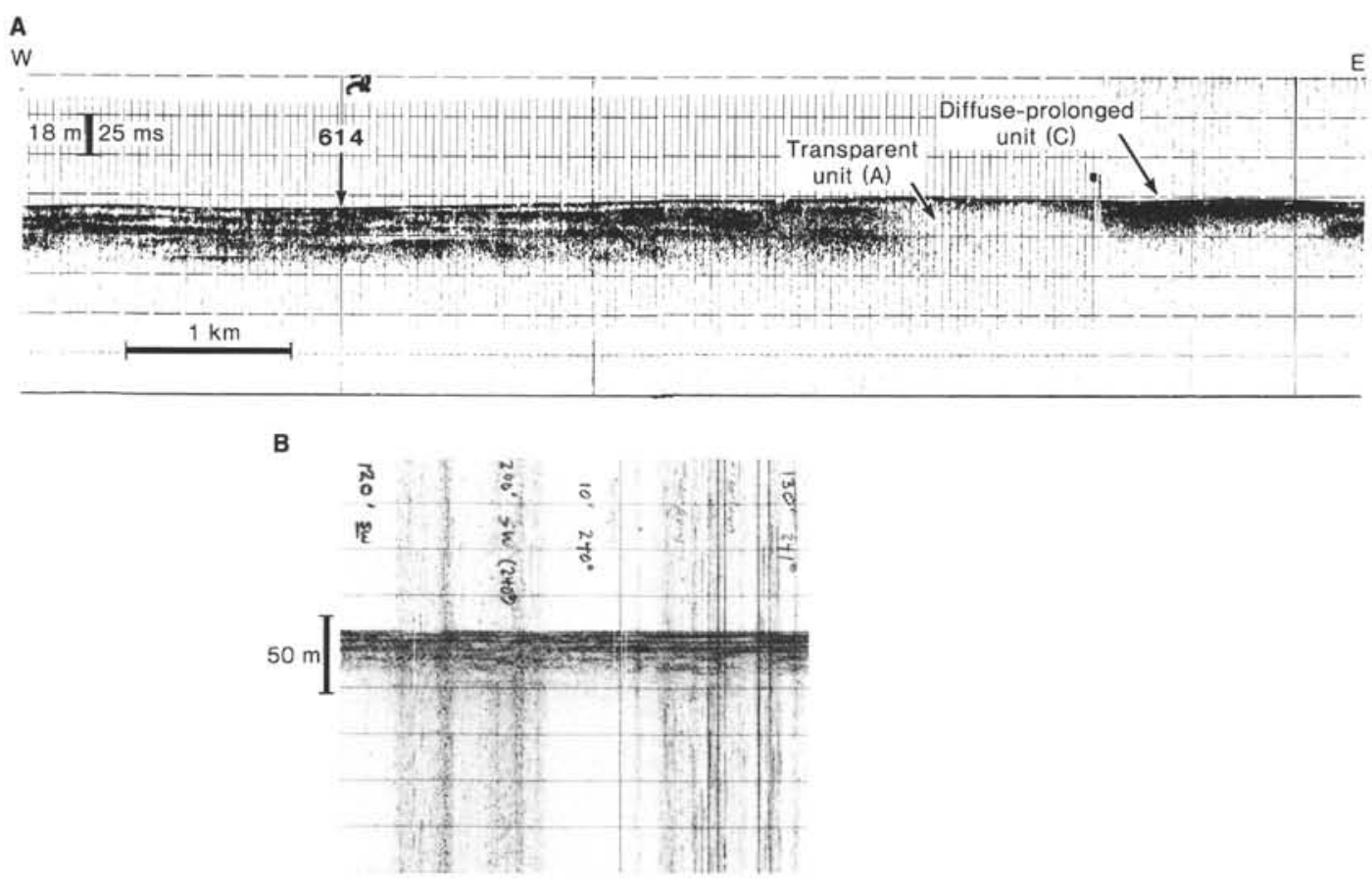

Figure 14. A. 3.5-kHz profile from site survey cruise (Conrad 23-12, Line 70) at Site 614. Location of profile shown in Figures $1 \mathrm{C}$ and 12. B. 3.5-kHz profile from the Glomar Challenger while positioning over beacon. The profile represents less than $200 \mathrm{~m}$ of movement, and these data were used to measure reflector depths for Table 4. 
Table 3. Depth to sub-bottom reflectors and assumed corresponding lithologic contacts at Site $615 .^{\mathrm{a}}$

\begin{tabular}{|c|c|c|c|}
\hline \multicolumn{2}{|c|}{ Reflectors } & \multicolumn{2}{|c|}{ Lithologic contacts } \\
\hline $\begin{array}{l}\text { Sub-bottom } \\
\text { depth } \\
\text { (ms) }\end{array}$ & $\begin{array}{l}\text { Sub-bottom } \\
\text { depth } \\
\text { (m) }\end{array}$ & $\begin{array}{l}\text { Sub-bottom } \\
\text { depth } \\
\text { (m) }\end{array}$ & Comments \\
\hline 5 & 3.5 & 3.6 & $\begin{array}{l}\text { Upper part of } 1-\text { to } 3-\mathrm{cm}- \\
\text { thick, coarse silt layer } \\
\text { with scoured bases }\end{array}$ \\
\hline 6 & 4.5 & 5.2 & $\begin{array}{l}\text { Uppermost very fine } \\
\text { sand bed, } 6 \mathrm{~cm} \text { thick }\end{array}$ \\
\hline 8 & 6.0 & 6.3 & $\begin{array}{l}\text { Top of } 25 \text {-cm-thick de- } \\
\text { formed silty mud bed }\end{array}$ \\
\hline 10 & 7.8 & & \\
\hline 11.5 & 8.7 & 9.1 & $\begin{array}{l}\text { Upper contact of } 3 \text { sand } \\
\text { layers in } 90-\mathrm{cm} \\
\text { section }\end{array}$ \\
\hline 15 & 11.5 & 11.3 & $\begin{array}{l}\text { 5-cm-thick, very-fine } \\
\text { sand bed }\end{array}$ \\
\hline & & 12.9 & 10-cm-thick sand bed \\
\hline 19 & 14.6 & 14.0 & $\begin{array}{l}50-\mathrm{cm} \text {-thick silt and sand } \\
\text { layer }\end{array}$ \\
\hline 20 & 15.4 & 15.2 & $\begin{array}{l}\text { 4.5-m-thick sand bed } \\
\text { (Fig. 15A) }\end{array}$ \\
\hline
\end{tabular}

${ }^{\mathrm{a}}$ From Glomar Challenger $3.5-\mathrm{kHz}$ profile (Fig. 13B).

20-m sub-bottom depth, individual mud/sand contacts are observed as distinct, sharp echo returns; (2) with increasing depth, only the thicker sands $(>10 \mathrm{~cm})$ are seen on the $3.5-\mathrm{kHz}$ profile; and (3) the diffuse-prolonged reflector character in the lower half (greater than $30 \mathrm{~m}$ sub-bottom) is related to a thick unit that is dominantly sand with a few thin mud interbeds.

\section{DISCUSSION AND CONCLUSIONS}

Combined use of both high-resolution (3.5- and 4.5$\mathrm{kHz}$ ) seismic profiles and the observations on the upper $50 \mathrm{~m}$ of sediment from hydraulic piston cores in the Mississippi Fan provides a useful approach to interpreting fan depositional processes. Surface and near-surface distribution of the acoustic facies units gives the areal extent of the different acoustic units. These acoustic facies have been correlated with sediment texture for other deep-sea fans, encouraging the interpretation of depositional processes (Normark, 1970; Normark and Gutmacher, 1983/84; Normark et al., 1979, 1983/84; Damuth and Kumar, 1975).

Four major acoustic units have been defined in this study of the Mississippi Fan. Table 5 lists the nine middle and lower Mississippi Fan sites, the acoustic units, and the type of sediment recovered. Correlation between acoustic response and predicted sediment type ranges from excellent to poor.

The best correlation occurs between Unit B and bedded sediments (Sites 614, 615, and 617). Not only were laminated and bedded sediments recovered, but as predicted, the coarseness and thickness of the beds also changed. An argument can also be made that specific beds and reflectors can be matched, although in this case the match is facilitated between the number of reflectors and lithologic boundaries. Correlation was also good at Site 616 where the hummocky reflectors predicted disturbed sediment and variably inclined bedded sediments were recovered.
Weaker correlation exists between both the transparent unit (A) and the diffuse-prolonged unit (C) and the recovered sediment. Site 621 was cored through the center of the $A_{1}$ and $A_{2}$ transparent units, and Site 622 penetrated these same units near their boundary with Unit C. A debris-flow deposit was predicted from interpretation of the transparent material (Kastens and Shor, 1985), but fine-grained material recovered makes identification of a debris-flow deposit difficult. The presence of seafloor-parallel laminations and poorly developed grading suggest that these sediments may have been deposited from a flow undergoing a debris flow to turbidity current transition.

Microscopic laminae in cores from the transparent channel fill raise the question of why reflectors were not observed in this material. The lack of reflectors may be because the sediments forming these thick transparent layers are predominantly homogeneous. For example, a major difference between these cores and those studied by Mayer $(1979,1980)$ and Flood and Shor (1984) is the very low and generally uniform carbonate content in these cores. The changes in carbonate content were responsible for producing the impedance contrast in the previous studies. Alternatively, the transparent return may result from acoustic scattering at the surface, rather than downhole lithologic changes. Side-scan images in this area (Prior et al., 1983; Kastens and Shor, 1985) show a wide variety of surface textures which may be capable of producing surface acoustic scatter.

Correlation of acoustic units and lithology is most variable between the diffuse-prolonged unit $(\mathrm{C})$ and the recovered material. Unit $C$ was clearly penetrated at Sites 614,615 , and 617 , beneath Unit B, and outcropping on the surface at Sites 623 and 624. This reflector type has been previously observed where the sediment contained numerous sand beds greater than $1 \mathrm{~m}$ thick (Damuth, 1975; Normark and Gutmacher, 1983/84; Normark et al., 1979, 1983/84). At Sites 614 and 615, Unit C was mapped as occurring at a specific sub-bottom depth (Tables 3 and 4), and at that depth the first sand layers were recovered, giving excellent correlation.

However, at Sites 617,623 , and 624 , no sand beds were recovered. At these sites, Unit $\mathrm{C}$ forms part of a fine-grained levee-overbank deposit. Additional possibilities for the generation of the diffuse-prolonged acoustic response at these sites include: (1) surface roughness; (2) the depth at which coarser or thicker layers appear, (3) undetected physical property or chemical changes, or (4) the presence of many fine laminae that produce an acoustic interference pattern. We favor both (1) and (4) as generators of Unit C. Levees form from the deposition of sediment by numerous flows, some of which are also erosive. This depositional environment could result in many short and truncated layers that are capable of scattering sound in a manner similar to coarser grained sediment.

In summary, acoustic facies from high-resolution seismic profiles are a valuable and important method for interpreting deep-sea depositional processes. Interpretation, however, should be done in conjunction with core analysis because multiple factors-such as composition, fre- 
A

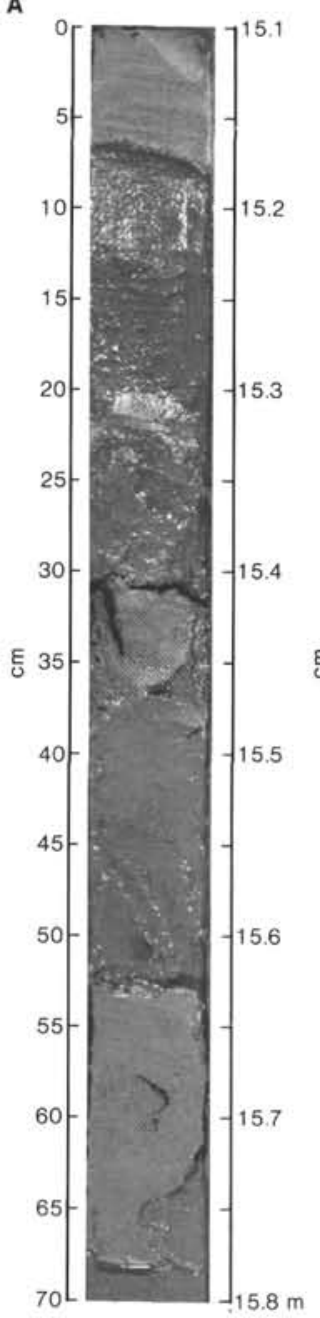

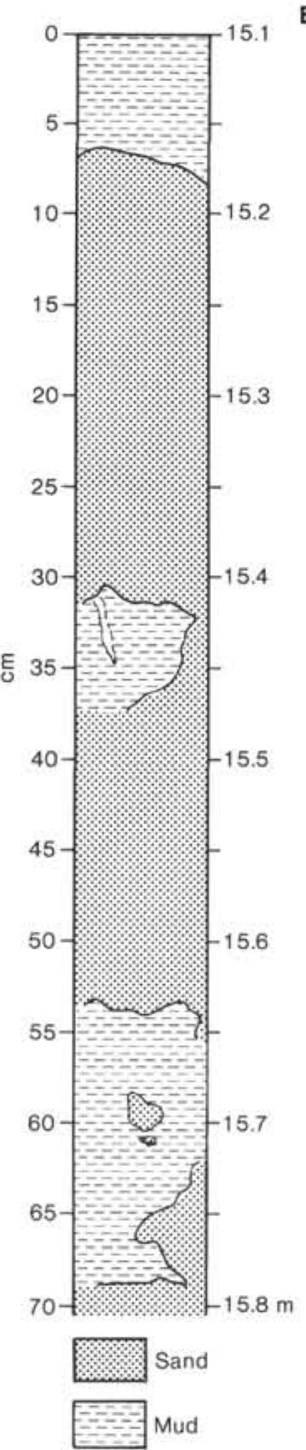

B

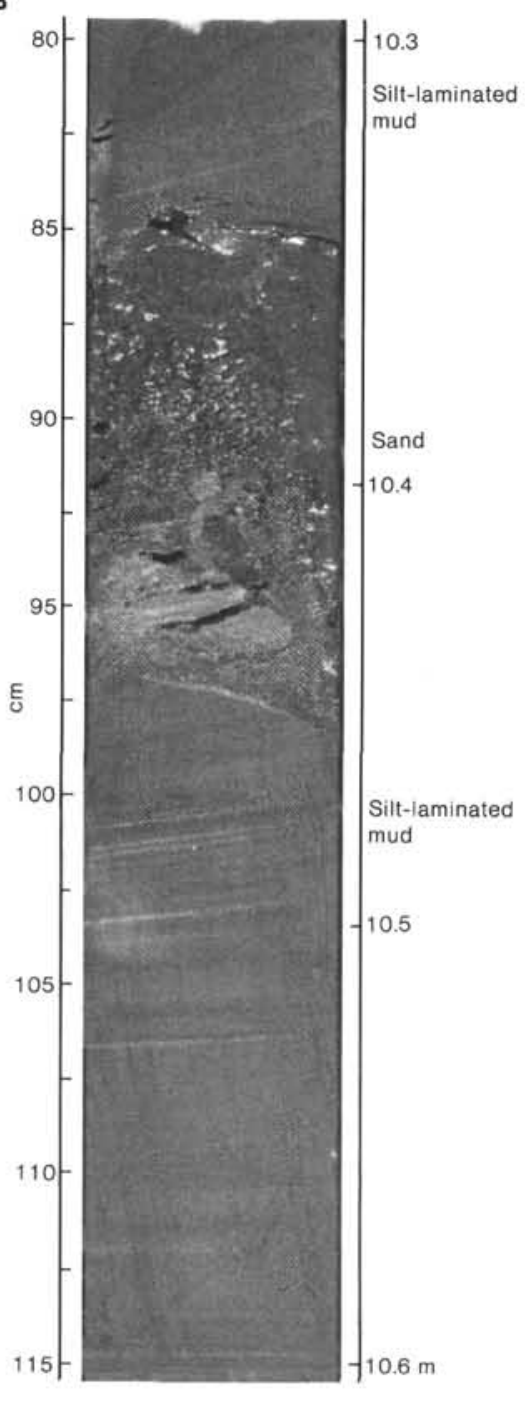

C

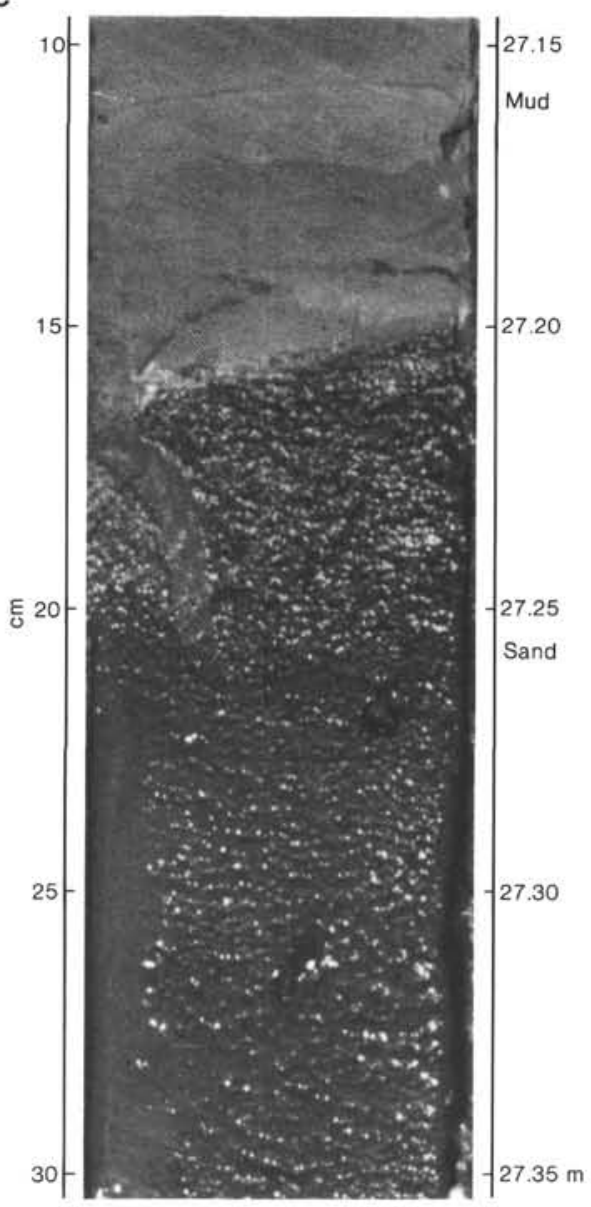

Figure 15. Photographs of core sections. A. Contact between mud and major sand layer, with some coring disturbance at Site 615 (Sample 615-3-3, 0-70 cm, 15.1-15.8 m sub-bottom). B. Silt-laminated mud and sand at Site 614 (Sample 614-2-1, 80-115 cm, 10.3-10.6 m sub-bottom). C. Contact between mud and major sand layer at $27.2 \mathrm{~m}$ sub-bottom at Site 614 (Sample 614-3-4, 10-30 cm).

quency, and thickness of layers-and surface texture may influence the response. Therefore the extrapolation of acoustic response and sediment type from one area to another, even within the same depositional system, may be variable and is best done with caution.

\section{ACKNOWLEDGMENTS}

We gratefully acknowledge reviews and discussions of this chapter by P. Carlson, H. Cook, J. Damuth, R. Flood, K. Kastens, and A. Shor. C. Brenner and the IPOD Data Bank were helpful in providing the reflection profiles used in this chapter. Any use of trade names or trademarks in this publication is for descriptive purposes only and does not constitute endorsement by the U.S. Geological Survey.

\section{REFERENCES}

Chayes, D. N., 1983. Evolution of Sea MARC I. I.E.E.E., Proceedings of Third Working Symposium on Oceanographic Data Systems, pp. 103-108.

Cook, H. E., Field, M. E., and Gardner, J. V., 1982. Continental slopes. In Scholle, P. A., and Spearing, D. R. (Eds.), Sandstone Depositional Environments: Tulsa (Am. Assoc. Pet. Geol. Mem. 31), pp. 329-364.
Cook, H. E., and Mullins, H. T., 1983. Basin margin environment. In Scholle, P. A., Bebout, D. G., and Moore, C. H. (Eds.), Carbonate Depositional Environments: Tulsa (Am. Assoc. Pet. Geol. Mem. 33), pp. 540-617.

Damuth, J. E., 1975. Echo character of the western equatorial Atlantic floor and its relationship to the dispersal and distribution of terrigenous sediments. Mar. Geol., 18:17-45.

1980. Use of high-frequency $(3.5-12 \mathrm{kHz})$ echograms in the study of near-bottom sedimentation processes in the deep-sea: a review. Mar. Geol., 38:51-75.

Damuth, J. E., and Kumar, N., 1975. Amazon cone: morphology, sediments, age and growth pattern. Geol. Soc. Am. Bull., 86:863-878.

Embley, R. W., 1975. Studies of deep-sea sedimentation processes using high-frequency seismic data. [Ph.D. Thesis]. Columbia University, New York.

1980. The role of mass transport in the distribution and character of deep-ocean sediments with special reference to the North Atlantic. Mar. Geol., 38:23-50.

Embley, R. W., and Jacobi, R., 1977. Distribution and morphology of large sediment slides and slumps on Atlantic continental margins. Mar. Geotechnol., 2:205-228.

Embley, R. W., and Johnson, D. A., 1980. Acoustic stratigraphy and biostratigraphy of Neogene carbonate horizons in the north equatorial Pacific. J. Geophys. Res., 85:5423-5437. 
Flood, R. D., and Bryan, G., 1983. Sediment velocity profiles from hydrophone-pinger experiment on the Mississippi Fan. In Conrad cruise report RC 23-12, unpublished, 26 pp.

Flood, R. D., and Hollister, C. D., 1974. Current-controlled topography on the continental margin off the eastern United States. In Burke, C. A., and Drake, C. L. (Eds.), The Geology of Continental Margins: New York (Springer), pp. 197-205.

Flood, R. D., and Shor, A. N., 1984. Synthetic seismogram generation from sediment composition data-an initial study in the southwest Brazil Basin. Mar. Geol., 58:263-274.

Jacobi, R. D., 1976. Sediment slides on the northwestern continental margin of Africa. Mar. Geol., 22:157-173.

Kastens, K. A., and Shor, A. N., 1985. Depositional processes of a meandering channel on the Mississippi Fan. Am. Assoc. Pet. Geol. Bull., 69:190-202.

Mayer, L. A., 1979. The origin of fine-scale acoustic stratigraphy in deep sea carbonates. J. Geophys. Res., 84:6177-6184. 1980. Deep-sea carbonates: physical property relationships and the origin of high-frequency reflectors. Mar. Geol., 38:165183.

Moore, G. T., Starke, G. W., Bonham, L. C., and Woodbury, H. O., 1978. Mississippi Fan, Gulf of Mexico-physiography, stratigraphy, and sedimentation patterns. In Bouma, A. H., Moore, G. T., and Coleman, J. M. (Eds.), Framework, Facies, and Oil-Trapping Characteristics of the Upper Continental Margin: Tulsa (Am. Assoc. Petrol. Geol.), AAPG Stud. Geol., 7:155-191.

Normark, W. R., 1970. Growth patterns of deep-sea fans. Am. Assoc. Pet. Geol. Bull., 54:2170-2195.

Normark, W. R., and Gutmacher, C. E., 1983/1984. Delgada Fan: Preliminary interpretation of channel development. Geo-Mar. Lett., 3:79-83.

Normark, W. R., Gutmacher, C. E., Chase, T. E., and Wilde, P., 1983/1984. Monterey Fan: Growth pattern controlled by basin morphology and changing sea levels. Geo-Mar. Lett., 3:93-99.

Normark, W. R., Piper, D. J. W., and Hess, G. R., 1979. Distributary channels, sand lobes and mesotopography of Navy submarine fan, California Borderland, with applications to ancient fan sediments. Sedimentology, 26:749-774.

Prior, D. B., Adams, C. E., and Coleman, J. M., 1983. Characteristics of a deep-sea channel on the middle Mississippi Fan as revealed by a high resolution survey. Trans. Gulf Coast Assoc. Geol. Soc., 23:389-394.

Roberts, H. H., and Thayer, P. L., 1985. Petrology of Mississippi depositional environments encountered in DSDP Leg 96 borings. In Bouma, A. H., Normark, W. R., and Barnes, N. (Eds.), Submarine Clastic Systems: Deep Sea Fans and Related Facies: New York (Springer Verlag), pp. 331-340.

Spiess, F. N., and Tyce, R. C., 1973. Marine Physical Laboratory deeptow instrumentation system. Scripps Institution of Oceanography Ref. 73-4.

Walker, J. R., and Massingill, J. V., 1970. Slump features on the Mississippi Fan, northeastern Gulf of Mexico. Geol. Soc. Am. Bull., 81:3101-3108.

Date of Initial Receipt: 21 February 1985

Date of Acceptance: 29 August 1985
Table 4. Depth to sub-bottom reflectors and assumed corresponding lithologic contacts at Site $614 .^{\mathrm{a}}$

\begin{tabular}{|c|c|c|c|}
\hline \multicolumn{2}{|c|}{ Reflectors } & \multicolumn{2}{|c|}{ Lithologic contacts } \\
\hline $\begin{array}{l}\text { Sub-bottom } \\
\text { depth } \\
\text { (ms) }\end{array}$ & $\begin{array}{l}\text { Sub-bottom } \\
\text { depth } \\
\text { (m) }\end{array}$ & $\begin{array}{l}\text { Sub-bottom } \\
\text { depth } \\
\text { (m) }\end{array}$ & Comments \\
\hline 3 & 2.3 & 2.35 & $\begin{array}{l}\text { Uppermost sandy silt bed, } \\
4 \mathrm{~cm} \text { thick }\end{array}$ \\
\hline 7 & 5.2 & 4.9 & $\begin{array}{l}\text { Thin (1-cm-thick) oxidized } \\
\text { and burrowed zone }\end{array}$ \\
\hline $13-14$ & 10.1 & 10.2 & 11-cm-thick sand bed \\
\hline 17 & 13.1 & $\begin{array}{l}13.0 \\
15.3\end{array}$ & $\begin{array}{l}\text { 14- } \mathrm{cm} \text { silt and sand beds } \\
29-\mathrm{cm} \text { silty sand bed }\end{array}$ \\
\hline 21 & 16.2 & $\begin{array}{l}16.2 \\
17.3 \\
18.9 \\
20.4\end{array}$ & $\begin{array}{l}8-\mathrm{cm} \text { sand bed } \\
22-\mathrm{cm} \text { silty sand bed } \\
20-\mathrm{cm} \text { sand bed } \\
97-\mathrm{cm} \text { muddy sand bed }\end{array}$ \\
\hline $30-31$ & 23.5 & $\begin{array}{l}23.5 \\
26.9\end{array}$ & $\begin{array}{l}2.16-\mathrm{m} \text { sand bed } \\
27-\mathrm{cm} \text { sand bed }\end{array}$ \\
\hline 36 & 27.5 & 27.2 & $\begin{array}{l}\text { 12-m sand bed (may be } \\
\text { flow-in from thinner } \\
\text { bed) }\end{array}$ \\
\hline
\end{tabular}

${ }^{\mathrm{a}}$ From Glomar Challenger $3.5-\mathrm{kHz}$ profile (Fig. 14B).

Table 5. Site morphology, acoustic facies, and sediment type.

\begin{tabular}{|c|c|c|c|}
\hline Site & Location & Acoustic facies & Sediment type \\
\hline 614 & $\begin{array}{l}\text { Downfan from channel } \\
\text { termination }\end{array}$ & $\begin{array}{l}\text { Multiple reflector } \\
\text { over diffuse } \\
\text { prolonged }\end{array}$ & $\begin{array}{l}\text { Mud and silt-laminated } \\
\text { mud over sand }\end{array}$ \\
\hline 615 & $\begin{array}{l}2 \mathrm{~km} \text { west of leveed } \\
\text { lower fan channel }\end{array}$ & $\begin{array}{l}\text { Multiple reflector } \\
\text { over diffuse } \\
\text { prolonged }\end{array}$ & $\begin{array}{l}\text { Mud and silt-laminated } \\
\text { mud over sand }\end{array}$ \\
\hline 617 & $\begin{array}{l}\text { Western side of midfan } \\
\text { levee }\end{array}$ & $\begin{array}{l}\text { Multiple reflector } \\
\text { over diffuse } \\
\text { prolonged }\end{array}$ & $\begin{array}{l}\text { Color-banded mud, } \\
\text { with thin silt } \\
\text { laminations that } \\
\text { increase downcore }\end{array}$ \\
\hline 620 & $\begin{array}{l}\text { Eastern side of midfan } \\
\text { channel overbank }\end{array}$ & Hummocky & $\begin{array}{l}\text { Mud in disturbed } \\
\text { rotary-drilled core }\end{array}$ \\
\hline 616 & $\begin{array}{l}\text { Eastern side of midfan } \\
\text { channel }\end{array}$ & Hummocky & $\begin{array}{l}\text { Variably inclined silt- } \\
\text { laminated mud }\end{array}$ \\
\hline 621 & $\begin{array}{l}\text { Midfan channel } \\
\text { thalweg }\end{array}$ & Transparent & $\begin{array}{l}\text { Visually homogeneous } \\
\text { mud }\end{array}$ \\
\hline 622 & $\begin{array}{l}\text { Midfan channel "point } \\
\text { bar" }\end{array}$ & Transparent & $\begin{array}{l}\text { Visually homogeneous } \\
\text { mud }\end{array}$ \\
\hline 623 & $\begin{array}{l}\text { Margin of lower fan } \\
\text { filled channel }\end{array}$ & $\begin{array}{l}\text { Diffuse pro- } \\
\text { longed }\end{array}$ & $\begin{array}{l}\text { Mud and silt-laminated } \\
\text { mud }\end{array}$ \\
\hline 624 & $\begin{array}{l}\text { Overbank of lower fan } \\
\text { filled channel }\end{array}$ & $\begin{array}{l}\text { Weak diffuse } \\
\text { prolonged }\end{array}$ & $\begin{array}{l}\text { Mud and thin silt- } \\
\text { laminated mud }\end{array}$ \\
\hline
\end{tabular}

